\title{
Emerging Roles of Sonic Hedgehog in Adult Neurological Diseases: Neurogenesis and Beyond
}

\author{
Shang-Der Chen ${ }^{1,2,3,+}$, Jenq-Lin Yang ${ }^{2,+}{ }^{(0)}$, Wei-Chao Hwang ${ }^{4}$ and Ding-I Yang ${ }^{5,6, *}$ \\ 1 Department of Neurology, Kaohsiung Chang Gung Memorial Hospital, Kaohsiung City 83301, Taiwan; \\ chensd@adm.cgmh.org.tw \\ 2 Institute for Translational Research in Biomedicine, Kaohsiung Chang Gung Memorial Hospital, \\ Kaohsiung City 83301, Taiwan; jyang@adm.cgmh.org.tw \\ 3 College of Medicine, Chang Gung University, Taoyuan City 33302, Taiwan \\ 4 Department of Neurology, Taipei City Hospital, Taipei 11556, Taiwan; huangshiaowei@gmail.com \\ 5 Institute of Brain Science, National Yang-Ming University, Taipei 11221, Taiwan \\ 6 Brain Research Center, National Yang-Ming University, Taipei 11221, Taiwan \\ * Correspondence: diyang@ym.edu.tw; Tel.: +886-2-28267386 \\ + These authors contributed equally to this work.
}

Received: 8 July 2018; Accepted: 13 August 2018; Published: 16 August 2018

\begin{abstract}
Sonic hedgehog (Shh), a member of the hedgehog (Hh) family, was originally recognized as a morphogen possessing critical characters for neural development during embryogenesis. Recently, however, Shh has emerged as an important modulator in adult neural tissues through different mechanisms such as neurogenesis, anti-oxidation, anti-inflammation, and autophagy. Therefore, Shh may potentially have clinical application in neurodegenerative diseases and brain injuries. In this article, we present some examples, including ours, to show different aspects of Shh signaling and how Shh agonists or mimetics are used to alter the neuronal fates in various disease models, both in vitro and in vivo. Other potential mechanisms that are discussed include alteration of mitochondrial function and anti-aging effect; both are critical for age-related neurodegenerative diseases. A thorough understanding of the protective mechanisms elicited by Shh may provide a rationale to design innovative therapeutic regimens for various neurodegenerative diseases.
\end{abstract}

Keywords: sonic hedgehog; neurogenesis; anti-oxidation; anti-inflammation; autophagy; neurodegenerative diseases

\section{Introduction}

The hedgehog gene $(\mathrm{Hh})$ was first discovered in the fruit fly Drosophila melanogaster by Christiane Nüsslein-Volhard and Eric Wieschaus, two Nobel Laureates who were devoted to studying the genetic control of early embryonic development [1]. The loss of function mutation of $H h$ results in small pointed projections covering the larvae that are similar to the spikes of a hedgehog $(H h)$, hence the name. In mammals, there are three $H h$ family members, namely sonic hedgehog (Shh), indian hedgehog (Ihh), and desert hedgehog $(D h h)$. Among them, Shh is the best-studied ligand of the hedgehog signaling pathway. Shh is a soluble extracellular protein that was originally discovered to carry a function in cellular differentiation in the neural tube and limb bud with the growth of digits [2].

It was later found that Shh signaling is critical to regulating a variety of developmental processes in the nervous system, such as differentiation of ventral forebrain neurons and midbrain dopaminergic neurons as well as proliferation and differentiation of cerebellar neuronal precursors [3-5]. In addition to the developmental specification of the cell fate, Shh signaling plays crucial roles in early patterning of the embryonic brain, notably to regulate polarity of the central nervous system (CNS) [6] as 
well as to guide the ventral patterning in the spinal cord [7]. These features are important for craniofacial development because disruption of Shh signaling pathway may cause craniofacial neural crest cell death, thereby resulting in craniofacial anomalies in both vertebrate models and human populations [8,9]. During early stages of head formation, Shh is produced in three key domains, namely neuroectoderm of the ventral forebrain, facial ectoderm, and the pharyngeal endoderm $[8,9]$. Shh signaling is critical for orchestrating the fundamental organization of the craniofacial region $[10,11]$. Deletion of Shh in mice results in major craniofacial defects, such as alobar holoprosencephaly, cyclopia [12], stomodeum [13], or hypoplasia in the first pharyngeal arch [14,15].

Hh signaling is also important for tumor formation. Aberrant activation of Hh pathway during adult life can lead to tumorigenesis in both basal cell carcinoma [16] and medulloblastoma [17]. Furthermore, improper activation of this pathway has been shown in a variety of other types of human cancers, such as those in the brain, breast, gastrointestinal system, lung, and prostate. Paracrine effect of Hh secretion from the tumor to the surrounding stroma can advance tumorigenesis. This pathway also regulates proliferation of cancer stem cells and enhances tumor invasiveness. The topics of $\mathrm{Hh}$ pathway in tumor formation and the related clinical application for cancer treatment have been well reviewed elsewhere [18-20] and will not be further discussed in this article.

It is now generally accepted that the mammalian Hh signaling relies on the primary cilium, a microtubule-based protrusion with an antenna-like structure in the plasma membrane [21]. Shh, a secreted glycoprotein, can bind to a plasma membrane receptor called Patched (Ptch). In the absence of Shh, Ptch maintains the transmembrane transducer Smoothened (Smo) in an inactive state and allows the transcription factor glioma-associated oncogene homolog (Gli) to be phosphorylated by casein kinase 1 (CK1), glycogen synthase kinase-3 (GSK3), and protein kinase A (PKA) [22]. These phosphorylation events lead to proteolytic cleavage of the full-length Gli into Gli repressor, which suppresses the expression of target genes and hence inactivates the Hh signaling pathway. On the contrary, in the presence of Shh, the inactivated Ptch relieves its suppression on Smo, which is then phosphorylated by CK1 and G protein-coupled receptor kinase 2 (GRK2) [23]. The inhibitory activity of suppressor of Fused (SUFU) on Gli is then relieved with subsequent activation of signal transduction pathways to induce the transcription of target genes [24,25] such as N-Myc [26], Bcl-2 [27,28], and Bmi1 [29] that participate, respectively, in the regulation of proliferation, survival, and self-renewal. A schematic overview of Hh signaling pathway is shown in Figure 1.

Robust neurogenesis in the cerebral cortex during the embryonic stage is significantly influenced by Shh, which possesses a pleiotropic effect to the developing CNS and directs neural cells into proliferation, specification, as well as growth of axons and dendrites in various CNS regions that include forebrain, hindbrain, and spinal cord. Shh also functions as a mitogen to regulate proliferation and survival of neural stem cells (NSCs)/neural progenitor cells (NPCs) [30]. In addition to its notable importance at the beginning of life, Shh plays a vital role in regulating proliferation of NPCs in adult hippocampus [31,32]. Decreased expression of Shh is associated with senescence, thereby rendering the body more susceptible to aging-related disorders [33]. Accordingly, an active Hh signaling is particularly crucial for maintaining the activity of neurons in adults [34]. Consistent with this notion, Ptch and Smo, the Shh receptors, are expressed in the adult hippocampus and in the NPCs derived from hippocampus [31,35].

Shh can regulate the response of the mature brain to various types of damages such as ischemic insult, brain injury, and neurodegeneration [36-38]. Shh signaling may also enhance or reduce the extent of reactive astrogliosis, depending on the time interval, injury severity, and the inflammatory response of an insult [30,37,39-41].

Several studies, including ours, reveal that manipulation of the Shh pathway carries therapeutic potential in neurodegenerative disorders and cerebral ischemia [42-48]. We have reported before that Shh mediates brain-derived neurotrophic factor (BDNF)-induced neuroprotection against 3-nitropropionic acid (3-NP), which is an irreversible inhibitor of mitochondrial succinate dehydrogenase, also known as Complex II in the electron respiratory chain, that has been used 
to investigate the molecular mechanisms concerning cell death, mitochondrial dysfunction, and neurodegeneration in Huntington's disease (HD) [47,49]. BDNF-mediated protection against 3-NP neurotoxicity was abolished by cyclopamine, the Shh pathway inhibitor. These results indicate that BDNF induces expression of Shh to mediate the beneficial effects against 3-NP neurotoxicity in rat cortical neurons [47]. We further validated that BDNF-dependent Shh expression and 3-NP resistance entail preceding induction of erythropoietin (EPO), thus verifying a signaling cascade of "BDNF $\rightarrow \mathrm{EPO} \rightarrow \mathrm{Shh} \rightarrow$ 3-NP resistance" in rat cortical neurons [46]. Recently, beneficial actions of Shh in ischemic injury have been noted [50-52]. By topical application of N-terminal fragment of Shh (Shh-N) and/or its specific inhibitor cyclopamine in fibrin glue over the peri-infarct cortex in the rat model of middle cerebral artery occlusion (MCAO), which mimics cerebral ischemia, we showed that Shh-N can attenuate protein oxidation and lipid peroxidation as well as increase neurogenesis and angiogenesis while decreasing astrocytosis [45]. It has also been demonstrated that, in hippocampal neurons, activation of the Shh signaling pathway may affect several features of mitochondrial function, such as increasing mitochondrial mass, inhibiting mitochondrial fission protein Drp1, and reducing mitochondrial fission while promoting mitochondrial elongation [53]. Shh can protect neurons against various stresses, including the amyloid $\beta$-peptide, high levels of glutamate, hydrogen peroxide, and rotenone, all are molecules or mediators related to ischemic injury or neurodegenerative diseases such as Alzheimer's disease (AD) and Parkinson's disease (PD) [53]. It is suggested that Shh may function as an anti-aging signal [33,54] based on several lines of evidence; these include the observations that the total Shh activity or inducibility are notably reduced in older animals [55], the age-related process of cellular senescence is blocked by active Shh signaling [56], and Shh-targeting drugs possess the potential to mitigate aging-related pathological conditions [57].

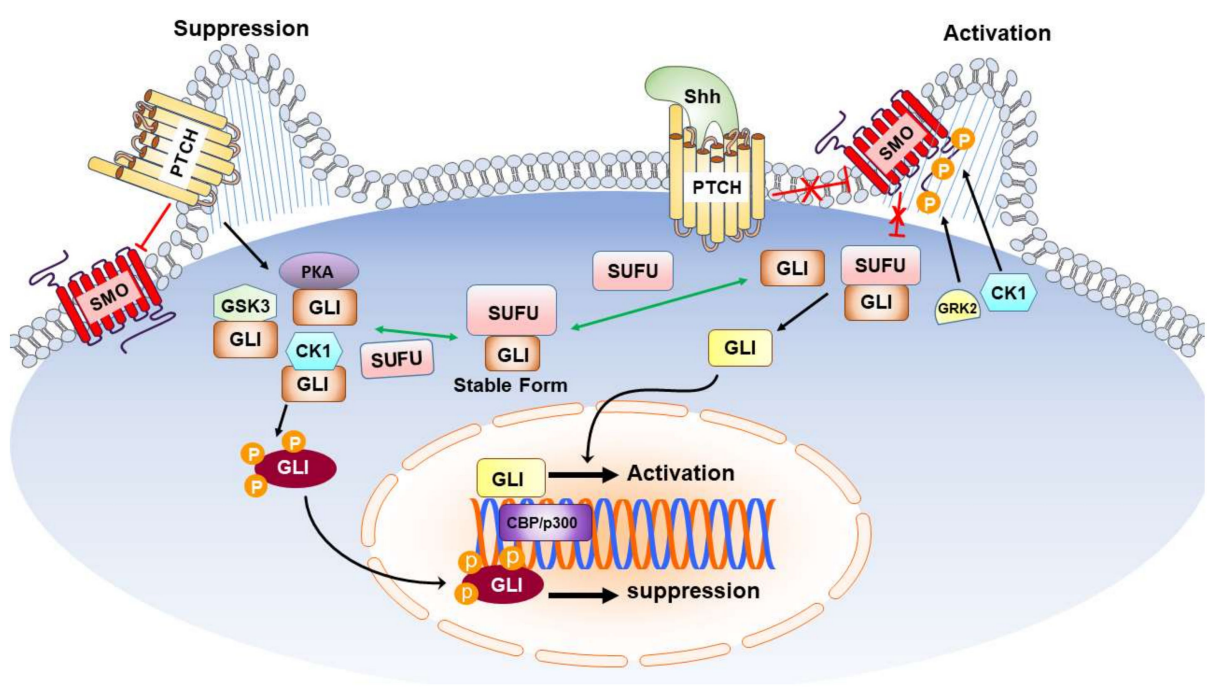

Figure 1. Sonic Hedgehog Signal Transduction Pathways. Shh acts on PTCH to relieve the inhibitory of PTCH on SMO, thereby activating the downstream pathway of SMO via binding with COS2. Upon binding of SMO to COS, Fu is released from COS2 complex and the freed Fu binds to SUFU to release GLI from SUFU complex. The freed GLI then enters the nucleus and, along with other transcription factors such as $\mathrm{CBP} / \mathrm{p} 300$, binds to the promoters of target genes to regulate their expression. Black arrows indicate promotion or increasing; red lines with a " $\mathrm{T}$ " and/or " $\mathrm{X}$ " indicate inhibition, suppression, or decreasing; green arrows indicate competition. Abbreviation: Shh: Sonic Hedgehog; PTCH: Patched; SMO: Smoothened; CBP: CREB-binding protein; COS2: Costal-2; Fu: protein Fused; SUFU: Suppressor of Fused.

The emerging multifaceted roles of Shh signaling under various neurological conditions are intriguing and the underlying mechanisms are worth further exploring. The role of Shh in mature neural tissue may provide therapeutic possibility, especially in devastating neurodegenerative 
disorders. In this article, we will focus on the potential action of Shh signaling in neurological diseases that may involve neurogenesis, anti-oxidation, anti-inflammation, and autophagy.

\section{Sonic Hedgehog and Neurogenesis in Neurological Diseases}

In the adult brain, neurogenesis continues in two regions: the subventricular zone (SVZ), which lines the lateral ventricles and gives rise to new interneurons that reach the olfactory bulb via the rostral migratory stream (RMS), and the subgranular zone (SGZ) of the dentate gyrus (DG) in hippocampus, which generates new granule cells [58]. Neurogenesis is modulated by both physiological stimuli, such as aging factor, exercise, learning, and genetic background [59-62] as well as pathophysiological conditions, such as seizure [63-65] and cerebral ischemia [66-68]. Manipulations, especially enhancement, of neurogenesis may carry therapeutic potential that can be applied in brain dysfunction with neuronal injury, such as cerebrovascular diseases and other neurodegenerative disorders.

Neurogenesis is important for neural tissues to renew, replace, and repair, thereby contributing to the maintenance of proper functions. The well-known regulators of neurogenesis in SVZ and SGZ include Wnt, bone morphogenetic protein (BMP), and Shh [69,70]. Several lines of evidence have revealed the crucial role of Shh in neurological diseases concerning the capability of neurogenesis [30,32,71] and, in this article, we will focus on Shh in neurogenesis as well.

Various compounds and drugs capable of modulating Shh pathway and neurogenesis have been tested. It was reported that salvianolic acid, an antioxidant and a free radical scavenger, promoted functional recovery and neurogenesis via activation of Shh after stroke in mice. It enhanced proliferation of NPCs and elevated long-term survival of newborn neurons in the SVZ; it also increased the expression of Shh and Ptch along with heightened nuclear translocation of Gli1 in the peri-infarct region, thereby causing robust production of BDNF and nerve growth factor. Notably, the Smo inhibitor cyclopamine markedly attenuated the beneficial outcomes of salvianolic acids [72], suggesting that Smo plays a crucial role in the observed protective mechanisms of salvianolic acids.

Resveratrol, a polyphenol derived from grapes, is known to have neuroprotective effects against ischemic stroke in the brains via various mechanisms such as anti-oxidation, anti-inflammation, and anti-apoptosis [73-75]. It was found that resveratrol considerably increased expression of Shh, Ptch-1, Smo, and Gli-1 at mRNA levels; furthermore, resveratrol also enhanced nuclear translocation of Gli-1. Inhibition of the Shh signaling pathway with the Smo inhibitor cyclopamine completely reversed the effects of resveratrol. These results suggest that resveratrol decreased cerebral ischemic injury and improved neurological function by upregulating Shh signaling pathway [76].

Epidemiologic evidence suggests that consumption of green tea is associated with reduced mortality of cardiovascular disease, inflammatory diseases, diabetes, and stroke as well as prevention and treatment of cancer [77,78]. Epigallocatechin-3-gallate (EGCG) is the major polyphenol and an active ingredient in green tea. It was shown that EGCG treatment significantly enhanced neurogenesis based on the increased numbers of 5-bromo-2'-deoxyuridine (BrdU)-labeled cells in the dentate gyrus of adult mice as well as in adult hippocampal NPCs. EGCG also triggered a vigorous upregulation of Shh signaling, namely expression of Ptch at mRNA and protein levels, as well as enhanced Gli expression in cultured NPCs; moreover, blockade of the Shh signaling attenuated EGCG-induced hippocampal neurogenesis [79].

In addition to those compounds derived from nature products like resveratrol and EGCG, small molecules capable of directly activating Shh signaling cascades have also been shown to enhance neurogenesis. For example, SAG, abbreviation for Smoothened AGonist, was isolated from the screening of 140,000 synthetic compounds using a Gli-luciferase reporter assay in mouse C3H10T1/2 cells $[80,81]$. Being a chlorobenzothiophene-containing Hh pathway agonist, SAG binds to the Smo heptahelical bundle in a manner similar to the Smo inhibitor cyclopamine [80]. In one study, SAG was administered 3-7 days after ischemic stroke in mice to enhance survival of newborn NSCs derived from both SVZ and SGZ in the ischemic brains. After one month of stroke, both cognitive function 
and locomotor activity were significantly improved in the SAG group compared to the vehicle group. These data validate a critical role of Shh pathway in post-stroke brain restoration and functional improvement. These results also indicate that modulation of Shh pathway can prolong treatment time window and could be a potential treatment strategy for ischemic stroke [82].

Neurogenesis impairment is considered a main determining factor of the intellectual incompetence observed in patients with Down Syndrome (DS), a genetic pathology caused by triplication of human chromosome 21 [83,84]. In a Ts65Dn mouse model of DS, it was demonstrated that the amyloid precursor protein (APP) triplicated gene impairs proliferation of NPCs from SVZ in the hippocampus $[85,86]$ because high levels of the intracellular domain from APP cleavage by $\gamma$-secretase can raise the transcription of Ptch1, which is known to repress Shh pathway $[85,86]$. ELND006 is an inhibitor of $\gamma$-secretase that restores the Shh pathway and fully recovers the impaired neurogenesis in Ts65Dn pups [87]. In another study, it was demonstrated that early inhibition of $\gamma$-secretase can improve brain development in DS [88]. These findings denote the potential therapeutic application of Shh in DS. Consistently, the Smo agonist SAG corrects the structural and cognitive deficits in the Ts65Dn mice; intriguingly, a single treatment of newborn mice with SAG results in normal cerebellar morphology, behavioral improvement in the Morris water maze task, and partial rescues of $\mathrm{N}$-methyl-D-aspartate (NMDA) receptor-dependent synaptic plasticity in adults [89]. These findings suggest that Shh agonists may carry therapeutic potential in the treatment of DS via enhancement of neurogenesis.

Cerebrolysin, a peptide preparation with various neurotrophic factors, can augment neurogenesis with better functional outcome in ischemic stroke and neurodegenerative diseases [90,91]. It was demonstrated that cyclopamine, which inhibits Smo in the Shh pathway, can fully reverse the beneficial actions of cerebrolysin on functional recovery of neurological deficits in the in vivo ischemic model [50]. Intrathecal delivery of recombinant Shh protein to the animals subject to ischemic stroke improved behavioral and functional recovery, which may be related to its effects on neurogenesis in the SVZ [92]. These results once again revealed the importance of Shh signaling pathway in enhancing neurogenesis under various neurological conditions, including cerebral ischemia.

Electroconvulsive seizure (ECS), a neuromodulatory modality to treat major depressive disorder [93], can enhance hippocampal neurogenesis, mossy fiber sprouting, synaptic reorganization, and neural plasticity in the adult brain [94-96]. It was demonstrated that ECS increases proliferation of adult hippocampal progenitors and these effects were fully blocked by cyclopamine, the pharmacological inhibitor of Shh signaling. These results suggest that the Shh pathway may be a critical mechanism for ECS to enhance adult hippocampal neurogenesis [97].

Enhancing endogenous stem cells and promoting regeneration of the injured nervous system may be vital approaches in patients suffering from brain injury. In an in vitro organotypic stretch injury model, it was shown that endogenous glial fibrillary acidic protein (GFAP)-positive NSCs/NPCs in the postnatal mouse cortex are activated following a stretch injury equivalent to a severe traumatic brain injury (TBI); intriguingly, these cells are likely to arise from the cortical parenchyma but not from the SVZ. More importantly, upregulation of Shh signaling following TBI was observed. Given the correlative evidence linking restoration of regenerative potential to upregulation of Shh pathway, these findings suggest a possibility of using this endogenous source of GFAP-positive stem cells for repair following TBI, in which Shh plays a key role in regulating their proliferation [98].

Reduction of neurogenesis in the brain is one of the main causes of dementia in AD and, on the contrary, modifying the course of hippocampal neurogenesis assists patients with AD [99]. It was shown that a massive shortfall in Ptch1 and Gli1 was observed in the hippocampus in the aged AD transgenic mice that would compromise the ability of genesis in both NSCs and glial precursor cells, although contents of these two proteins were substantially higher at young ages. The comparable findings in autopsied AD brains confirmed this discovery in the mouse model [100]. These observations suggest that deregulation of Ptch1-Gli1 signaling may result in abnormal loss of NSCs and glial precursor cells, thus contributing to cognitive decline in AD brains. 
Administration of kainic acid (KA) into rodents, which results in hippocampal damage, neuronal death, and seizures, is a well-characterized model to study human neurodegeneration [101,102]. It was shown that KA induces hippocampal neuronal death along with activation of microglia and astrocytes. The mitogen Shh is upregulated in reactive astrocytes in response to the insults and modulates astrocyte activation and proliferation. The activated Shh-Gli pathway in various glial cells is responsible for proliferation in post-neurodegenerative lesions [39].

Various approaches may be applied to enhance neurogenesis under different neurological conditions. Umbilical cord blood mononuclear cells (UCBMC) can alleviate brain damage $[103,104]$ and promote the proliferation of endogenous NSCs [105]. UCBMC, delivered at $24 \mathrm{~h}$ after hypoxia/ischemia (HI) in neonatal rats, can advance neuronal differentiation and decrease glial differentiation in the cerebral cortex via the Hh signaling pathway [106].

Overall, understanding how Shh signaling is affected under various neurological conditions and precise control of the Shh signaling, and hence the capability of neurogenesis, is crucial in future clinical application of Shh pathway in those neurodegenerative disorders in which neurogenesis plays a pivotal role.

\section{Sonic Hedgehog and Antioxidation in Neurological Diseases}

It is well known that living cells can produce excessive reactive oxygen species (ROS) under various stimuli such as hypoxia, serum deprivation, and cytokine stimulation [107,108]. Multiple sources of ROS exist that include NADPH oxidase, 5-lipoxygenase, and mitochondria [109]. Among them, mitochondria are the major organelle that produces ROS within cells [110-112]. During aerobic respiration, free electrons on the mitochondria may leak out from electron transport chain to react with molecular oxygen, thus producing superoxide anion as metabolic byproducts. Nitric oxide (NO) can react with superoxide anion to generate the highly reactive peroxynitrite anion $\left(\mathrm{ONOO}^{-}\right)$ that modifies and damages DNA, proteins, and lipids. Collectively, modification of these cellular macromolecules by ROS and/or reactive nitrogen species (RNS) plays an important role in a number of different physiological/pathological conditions, particularly aging, cancer, ischemia-reperfusion injury, and chronic neurodegeneration [113-116]. Counteracting the formation of excessive ROS via endogenous antioxidative mechanisms is critical for cells to survive and decreasing the ROS formation should have positive impacts in treating ROS-related disorders, including cerebral ischemia and neurodegenerative diseases. Recent studies have indicated that the Shh signaling pathway is involved in these diseases, but the underlying mechanisms remain to be clarified in terms of counteracting excessive ROS production [32].

It was shown that exposure of primary cortical neurons to hydrogen peroxide $\left(\mathrm{H}_{2} \mathrm{O}_{2}\right)$ decreased cell viability and inhibition of endogenous Shh signaling further aggravated the detrimental effect of $\mathrm{H}_{2} \mathrm{O}_{2}$ in neurons. Exogenous Shh increased the activities of glutathione peroxidase (GSH-PX) and superoxide dismutase (SOD), attenuated malondialdehyde (MDA) formation, promoted the expression of anti-apoptotic Bcl-2, and suppressed expression of pro-apoptotic Bax in $\mathrm{H}_{2} \mathrm{O}_{2}$-treated neurons. Expression of two neurotrophic factors, namely vascular endothelial growth factor (VEGF) and BDNF, was increased with Shh activation. These findings reveal that enhancement of Shh signaling can protect cortical neurons against oxidative damage and apoptosis, thus denoting a potential role of Shh for the therapeutic effects in brain ischemia and other neurodegenerative disorders [117]. It was also reported that exogenous Shh could augment the expression of p-Akt and diminish the activity of p-ERK, suggesting that $\mathrm{Shh} / \mathrm{PI} 3 \mathrm{~K} / \mathrm{Bcl}-2$ pathway may be involved in the protection of neurons against $\mathrm{H}_{2} \mathrm{O}_{2}$-induced oxidative stress and apoptosis [118]. In a similar in vitro model, it was demonstrated that Shh, acting as a prosurvival factor, plays a crucial part in neurite outgrowth in the $\mathrm{H}_{2} \mathrm{O}_{2}$-treated cortical neurons. Potential mechanisms underlying the antioxidative efficacies of Shh may include counteracting ROS release, prevention of mitochondrial dysfunction, promotion of ATP production, as well as preservation of mitochondrial complex II activities against oxidative stress [119]. 
It was shown that subarachnoid hemorrhage (SAH) increased mRNA and protein levels of Shh, Ptch1, and Gli-1 in the cerebral cortex. Cyclopamine, inhibitor of Smo in the Shh pathway, augmented the MDA formation and reduced the enzyme activities of SOD and GSH-Px in the brain. These results suggest that Shh pathway may play a protective role in $\mathrm{SAH}$, notably by preventing oxidative stress in cortex via activation of antioxidative and detoxifying enzymes [120]. In another study, purmorphamine (PUR), another agonist of Smo in addition to SAG, enhanced the expression of Shh and Gli that was decreased by SAH while attenuating SAH-dependent induction of Ptch and resulted in protection; all of these PUR actions were blocked by cyclopamine. Mechanistically, PUR treatment markedly decreased MDA content that was accompanied by the heightened expression of nuclear factor erythroid 2-related factor 2 (Nrf2) and its target gene heme oxygenase-1 (HO-1). Thus, the effect of PUR against SAH-induced injury in rats may be mediated in part by anti-apoptotic and antioxidative mechanisms, increased pERK levels, and enhanced Shh signaling in the frontal cortex [121].

Gli1 and Ptch1 are critical effectors in the Shh pathway; indeed, both of them are also transcriptional targets downstream of Shh signaling. In a rat model of cerebral ischemia, inhibition of Shh pathway led to decreased expression of Gli1, Ptch1, and SOD1 in ischemia-affected brain tissue accompanied by increased brain water content, infarct volume, and behavioral deficits. All these results imply that reduction of Shh signaling pathway aggravates ischemic injury in rats that is associated with down-regulation of Gli1, Ptch1, and SOD1 [36].

The underlying mechanisms of autism spectrum disorders (ASD) are still not clear [122]; however, as with other neurodegenerative diseases, oxidative stress may play a pathological role in this brain disorder [123]. It was demonstrated that autistic children had a notably higher level of ROS; further, heightened serum contents of Shh protein were detected in the children of autism, whereas BDNF content was considerably reduced in mild, but not severe, form of autistic children. This study demonstrates a correlation among Shh, BDNF, and ROS in autistic children and suggests a critical role of oxidative stress and Shh in ASD [124].

Oxidized low-density lipoprotein (oxLDL) increases the expression of pro-inflammatory genes, resulting in monocyte recruitment into the vessel wall with dysfunction of vascular endothelial cells [125]. oxLDL is elevated under several neurological conditions and induces disruption of blood-brain barrier (BBB) with resultant formation of cerebral edema [126]. Treatment of murine brain microvascular endothelial cells (MBMECs) with oxLDL increased intracellular ROS and MDA formation, decreased NO release, and reduced cell viability. These effects also involve the Shh signaling. This is because the mRNA and protein levels of Shh, Smo, and Gli1 were all considerably decreased after incubation with oxLDL, while overexpression of Shh diminished oxLDL-induced elevation of permeability in MBMECs. These results may denote the potential role of Shh pathway in BBB dysfunction with therapeutic implication in various neurological disorders [127,128].

Despite limited studies implicating Shh signaling pathway in neurological disorders, especially in neurodegenerative diseases, emerging evidence revealed that this pathway may play an important role in counteracting oxidative stress. Additional evidence also shows that Shh may act like an immediate early gene that is expressed quickly in response to acute insults to exert its beneficial effects $[117,129,130]$ with activation of the endogenous neuroprotective mechanisms. More studies are needed to support this notion and develop an efficacious therapeutic regimen in this regard especially in neurodegenerative diseases.

\section{Sonic Hedgehog and Anti-Inflammation in Neurological Diseases}

It is well-known that inflammation may play a crucial role in the pathogenesis of neurodegenerative diseases such as AD, amyotrophic lateral sclerosis (ALS), Parkinson's disease (PD), and multiple sclerosis (MS). Despite various etiologies such as genetic mutations, infections, misfolded proteins, and brain injury, neuronal damages often involve both adaptive and innate immune systems at various stages of disease in the CNS [131,132]. Inflammation-related signaling pathways in neurological disorders includes the Toll-like receptors pathway, the mitogen-activated protein kinases pathway, 
and the nuclear factor-kappa B pathway. In particular, mutual interaction has been noted in inflammation and oxidative stress. For instance, superoxide anion from NADPH oxidase in activated microglia may interact with NO produced during inflammatory responses to form the active oxidant peroxynitrite [133]. Given that these responses may have direct impacts on disease progression, they could serve as the targets for therapeutic intervention.

Evidence showed that Shh signaling pathway plays a role in coping with ROS overproduction under conditions of neurological diseases $[36,117,121]$ and is also possibly involved in inflammatory reactions. It was reported that Shh pathway is activated by acute brain injury and regulated by injury-related inflammation [37]. Shh pathway is intensively induced three days after brain injury and returns to baseline condition by 14 days. Shh expression correlates with Gli activation and is confined to those reactive astrocytes with GFAP expression. Blockade of Shh pathway by cyclopamine decreases Gli expression and attenuates considerably the extents of proliferation with reduction in the numbers of reactive astrocytes in the injured cortex [37].

In KA-induced neurodegeneration, the Shh expression is increased in reactive astrocytes. The peak activity of Shh was detected at seven days along with increased Gli activity and heightened proliferation in several types of glial cells. Thus, the Shh/Gli pathway is activated and leads to proliferation of reactive glial cells in response to KA-induced lesions [39].

The BBB that is composed of astrocytes, capillary endothelial cells, and pericytes is important for CNS homeostasis. The BBB function is altered in a number of neurological diseases like AD, PD, ALS, stroke, epilepsy, and brain trauma $[134,135]$. Several studies revealed that compromised integrity of BBB or its dysfunction may involve Shh pathway during inflammation [136-139]. Shh released from astrocytes plays an important role in the maintenance of BBB integrity [140]. Through diminishing expression of proinflammatory mediators and adhesion/migration of leukocytes, Shh can promote the quiescence of immune response in endothelial cells of BBB both in vivo and in vitro [140]. Further, it was shown that interleukin-1 $\beta$ (IL-1 $\beta$ ) induces BBB disruption by downregulating Shh expression in astrocytes. Enhancing the expression of astrocytic Shh may carry a therapeutic potential to restore disrupted BBB in patients with various neurological diseases [141].

Wip1, a nuclear phosphatase that can be activated under various types of stresses, is involved in aging, neuroinflammation, neurogenesis, and tumorigenesis [142-146]. A cross-talk between Wip1 pathways and Shh may accelerate tumorigenesis [147]. Wip1 can regulate lipopolysaccharide (LPS)-induced BBB dysfunction and neuroinflammation through Shh signaling pathway. Silencing of Wip1 can increase inflammatory cytokines such as IL-1 $\beta$, IL-6, IL-12, and tumor necrosis factor- $\alpha$ (TNF- $\alpha$ ) of the BBB induced by LPS, while overexpression of Wip1 results in an opposite effect in the expression of these cytokines and decreases the extent of inflammatory response. Consistent with the above findings, Wip1 overexpression increases Shh signaling and silencing of Wip1 represses Shh. These results indicate that Wip1 may counteract LPS-induced inflammatory response and BBB disruption while maintaining the BBB integrity via augmentation of Shh signaling [137].

BBB dysfunction may involve increased matrix metalloproteinase-9 (MMP-9) activity and breakdown of tight junction protein (TJP) [136,148,149]. CNS tuberculosis has a high mortality and morbidity associated with severe inflammation and BBB dysfunction [150,151]. In a co-culture model to study BBB integrity, which includes endothelial cells and astrocytes with conditioned medium from Mycobacterium tuberculosis (Mtb)-infected monocytes, expression of TJP is regulated by Shh via transcription factor Gli-1. The breakdown of TJP is related to secretion of MMP-9. SAG, exogenous Shh, or knockdown of MMP-9 expression can decrease BBB permeability and increase the expression of TJP in the Mtb-stimulated co-cultures [136]. These findings denote the relevance of Shh pathway in BBB integrity in CNS inflammation and infection.

Human immunodeficiency virus type-1 (HIV)-associated neurocognitive disorder (HAND) includes asymptomatic neurocognitive impairment, mild neurocognitive disorder, and HIV-associated dementia [152]. The activated/infected leukocytes are recruited into CNS through disrupted BBB due to persistent neuroinflammatory conditions. Using a rodent model of HAND, administration of SAG 
restored BBB integrity and also ameliorated the neuropathological deficits in infected mice. These results suggest that Shh signaling carries a therapeutic potential in HAND [138,139].

Several examples are presented here to show the pivotal role of Shh signaling pathway in inflammation-related neurological diseases. Potential use of SAG or Shh mimetic to counteract the inflammatory status offers a therapeutic option in term of mutual reaction between oxidative stress and inflammation; both are significant contributors to various neurodegenerative diseases. Additional future studies will provide evidence to support the beneficial effect of these Shh-related compounds for future clinical use.

\section{Sonic Hedgehog and Autophagy in Neurological Diseases}

Autophagy, a highly regulated process that breaks down organelles and macromolecules through lysosomal degradation, is essential for maintenance of intracellular homeostasis while the cell is under starvation, differentiation, and normal growth control $[153,154]$. Autophagy may function as a pro-survival mechanism throughout the period of nutrient shortage when cytoplasmic contents are reprocessed for ATP generation and production of nascent macromolecules. The role of autophagy in neurodegenerative diseases is just beginning to be elucidated [155-157]. Various insults during neurodegeneration can cause oxidative stress that damages multiple intracellular molecules. Thus, effective clearance of damaged organelles to break down the macromolecules for generation of building blocks, such as amino acids and nucleotides, for salvage would be protective under starvation conditions. Furthermore, removal of damaged organelles may also prevent apoptosis, especially when mitochondrial integrity is compromised. Through collaboration with ubiquitin-proteasome system [158], the protective role of autophagy in neurodegenerative process may be attributable to its ability to clear protein aggregates and damaged cytoplasmic organelles [159]. In contrast, defective autophagy may contribute to the pathogenesis of aging and neurodegenerative diseases [160]. However, uncontrollable autophagy would lead to aggressive digestion of affected neurons leading ultimately to neuronal death $[161,162]$.

The induction of autophagy has been shown in mouse cortex and striatum after various brain insults including ischemia or during progression of various neurodegenerative diseases such as $A D$, PD, and HD [163-167]. The microtubule-associated protein 1 light chain 3 (LC-3) is a marker protein for autophagy as it is required for autophagosome formation via its conversion from cytosolic LC3-I to membrane-bound LC3-II [168]. Genetic deletion of essential autophagy genes Atg 5 and 7 in mice results in neurodegeneration suggesting that autophagy is vital for normal neuronal function [169]. Nevertheless, autophagy could be a double-edged sword: it is protective in response to mild stress, but it could also be stressful and detrimental to neuronal survival as a result of over-activation by a more severe stress such as serious ischemia [170]. Delineation of the role of autophagy in various neurological conditions may broaden our knowledge and enhance our ability to manipulate the potential cell survival or death pathways and mitigate the neuronal injury.

Using the autophagy marker LC-3 by immunoblot analysis and immunocytochemistry, it was reported that autophagy pathway in Shh-exposed neurons was activated. Autophagosomes and various associated morphological changes were found in synaptic terminals in Shh-exposed neurons and the Shh-induced autophagy was dependent on class III Phosphatidylinositol 3-kinase complexes (PtdIns3K) [171]. However, whether Shh signaling can protect neurons against dysfunction and degeneration in AD or other neurodegenerative disorders still awaits elucidation. Evidence revealed the connection between Shh and autophagy because the Hh signaling pathway reduced the formation of autophagosome, both under basal as well as autophagy-induced conditions. The potential implications of Shh in autophagy is the ability to control protein homeostasis under physiological and pathological conditions [172]. Despite limited studies concerning Shh and autophagy reported in neural cells [171], numerous previous studies referring to Shh and autophagy in the disorders of other systems should inspire future investigation of Shh in relation to autophagy under normal as well as diseased neurological conditions [173-176]. 
In the intestinal epithelial cells derived from the Shh conditional knockout mice, it was shown that loss of Shh can alter ileal secretory cell maturation with endoplasmic reticulum stress and an evident reduction in autophagy [175]. Dysregulation of miRNAs, a contributing factor to autophagy, is implicated in a range of pathological conditions, including hepatic fibrosis. Among them, miR-148a interacts with the $3^{\prime}$-untranslated regions (3'-UTRs) of growth arrest-specific gene 1 (Gas1) transcripts to inhibit its expression. Gas1 encodes a surface binding receptor for $\mathrm{Hh}$ and assists the Shh signaling pathway in reducing autophagosome formation and thus have the potential to serve as a target for future development of novel therapeutic strategies against related diseases [173].

Shh pathway has been reported to protect cardiomyocytes in myocardial infarction (MI), but the underlying mechanism is not well defined [177,178]. It was revealed that Shh triggers AMPK-dependent autophagy in cardiomyocytes under oxygen glucose deprivation (OGD), a model mimicking the ischemic condition. SAG, the Shh pathway agonist, increased the expression of LC3-II and caused the formation of autophagosomes. These results indicate an important function of autophagy in Shh-induced cellular protection [174].

Autophagy in vascular smooth muscle cells (SMCs) is known to increase plaque stability $[179,180]$. Shh is expressed in atherosclerotic lesions and stimulates proliferation of vascular SMCs. It was demonstrated that both LC3-II and Shh protein expression were augmented within SMCs of neointimal lesions in the common carotid artery of mouse. Overexpression of mouse Shh in vascular SMCs increased the levels of LC3-II and also stimulated AKT phosphorylation. Shh-induced autophagy was further confirmed by the formation of autophagosomes as detected by immunostaining and electron microscopy, which was inhibited by AKT inhibitor IV. Shh promoted SMC proliferation, which was impeded not only by AKT inhibitor IV but also by cyclopamine. These findings suggest that Shh enhances autophagy of vascular SMCs by engaging AKT activation, thus indicating a crucial role of autophagy in Shh-induced cellular effects [176].

In the future studies of patients with neurodegenerative diseases or animal models of neurological disorders, manipulation of Shh signaling and alteration of autophagy by pharmacological or molecular approaches will improve our understanding towards these diseases and may guide the way to novel methods for their prevention and treatment.

\section{Conclusions and Future Perspectives}

Shh, originally revealed as a mitogen and crucial for development including CNS patterning and polarity, is now appreciated for its various functions to cope with different types of stresses. These include mitigation of oxidative stress and inflammation as well as modulation of autophagy-related mechanisms to help our body adjust to environmental challenge. In addition, Shh pathway also improves mitochondrial function and carries an antiaging effect. The potential protective mechanisms of Shh in adult neurological disorders are shown in Figure 2. More studies are needed to support the crucial roles of Shh signaling pathway in adult neurological disease, especially in neurodegenerative diseases currently without effective treatment, such as AD, PD and HD. Small molecules or compounds capable of activating Shh pathway may have the potential to treat or delay the progression of these devastating neurological disorders. 


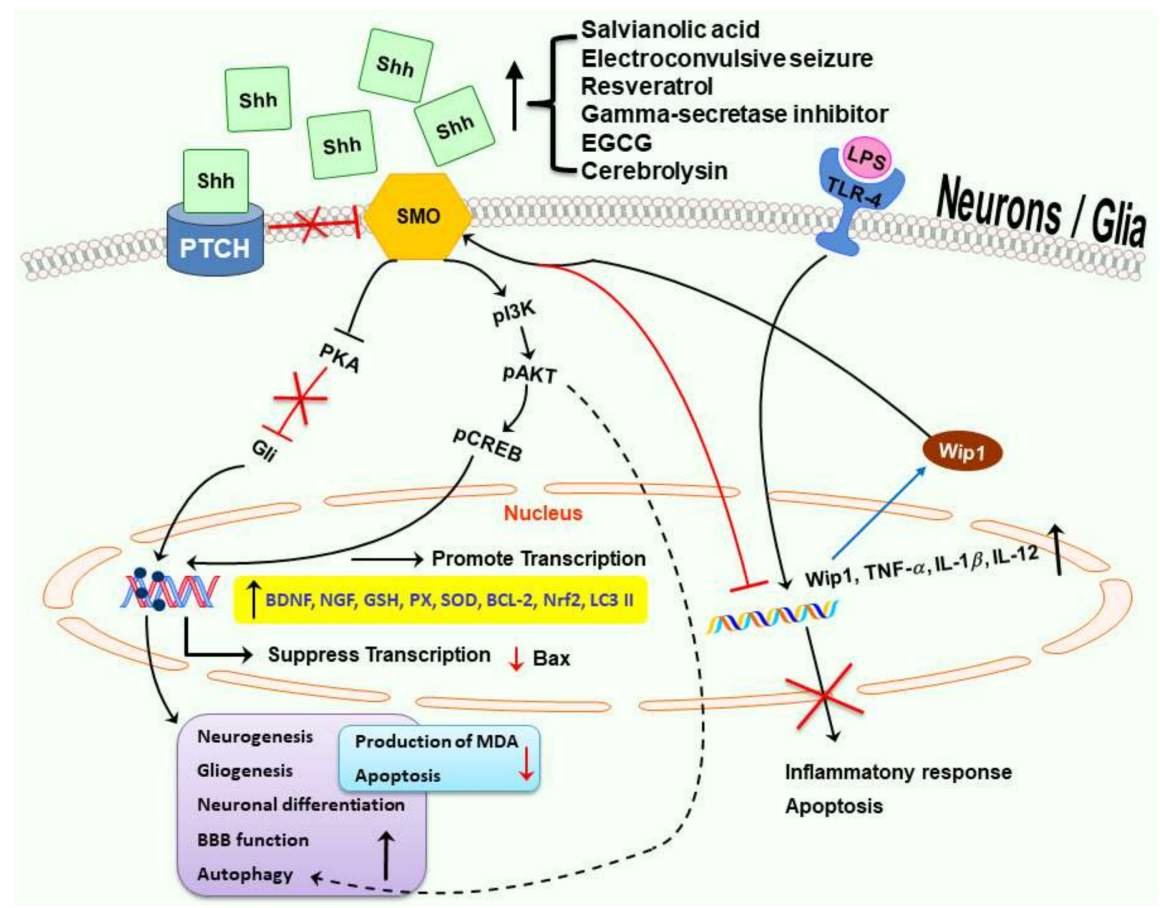

Figure 2. Multiple potential neuroprotective mechanisms in Shh signaling pathway. In the presence of Shh, inactivated Ptch relieves its suppression on Smo to activate several downstream pathways. The neuroprotective mechanisms of Shh may involve enhancement of neurogenesis, gliogenesis, autophagy, mitochondrial function, BBB function, anti-oxidation, anti-inflammation, and anti-apoptosis. Black solid or dashed arrows indicate promotion or increasing; red lines with an " $\mathrm{T}$ " and/or " $\mathrm{X}$ " indicate inhibition, suppression, or decreasing; blue arrows indicate translation.

Author Contributions: S.-D.C.: contributed to concept generation, data interpretation, drafting of the manuscript; D.-I.Y.: contributed to concept generation, data interpretation, approval of the article; J.-L.Y.: contributed to concept generation, data interpretation and approval of the article, W.-C.H.: contributed to data interpretation, approval of the article.

Funding: This work was supported by Ministry of Science and Technology (MOST) in Taiwan (MOST 103-2314-B-010-013-MY3, MOST 104-2314-B-010-014-MY2, MOST 106-2314-B-010-018-MY3, and MOST 107-2314-B-010-020-MY3 to DI Yang; MOST 106-2314-B-182-031 to SD Chen; MOST 106-2314-B-182A-002 to JL Yang), Department of Health in Taipei City Government (10501-62-050 and 10601-62-003 to DI Yang and WC Hwang), and Chang Gung Medical Foundation, Taiwan (CMRPG8F1891, CMRPG8F1892 to SD Chen, and CMRPG8F1512 to JL Yang). This work was also financially supported in part by the Brain Research Center, National Yang-Ming University from The Featured Areas Research Center Program within the framework of the Higher Education Sprout Project by the Ministry of Education (MOE) in Taiwan (107BRC-B408 to DI Yang).

Conflicts of Interest: The authors declare no conflict of interest.

$\begin{array}{ll}\text { Abbreviations } \\ \text { 3-NP } & \text { 3-nitropropionic acid } \\ \text { AD } & \text { Alzheimer's disease } \\ \text { ALS } & \text { amyotrophic lateral sclerosis } \\ \text { APP } & \text { amyloid precursor protein } \\ \text { ASD } & \text { autism spectrum disorders } \\ \text { BBB } & \text { blood-brain barrier } \\ \text { BDNF } & \text { brain-derived neurotrophic factor } \\ \text { BMP } & \text { bone morphogenetic protein } \\ \text { BrdU } & \text { 5-bromo-2'-deoxyuridine } \\ \text { CK1 } & \text { casein kinase 1 } \\ \text { CNS } & \text { central nervous system }\end{array}$




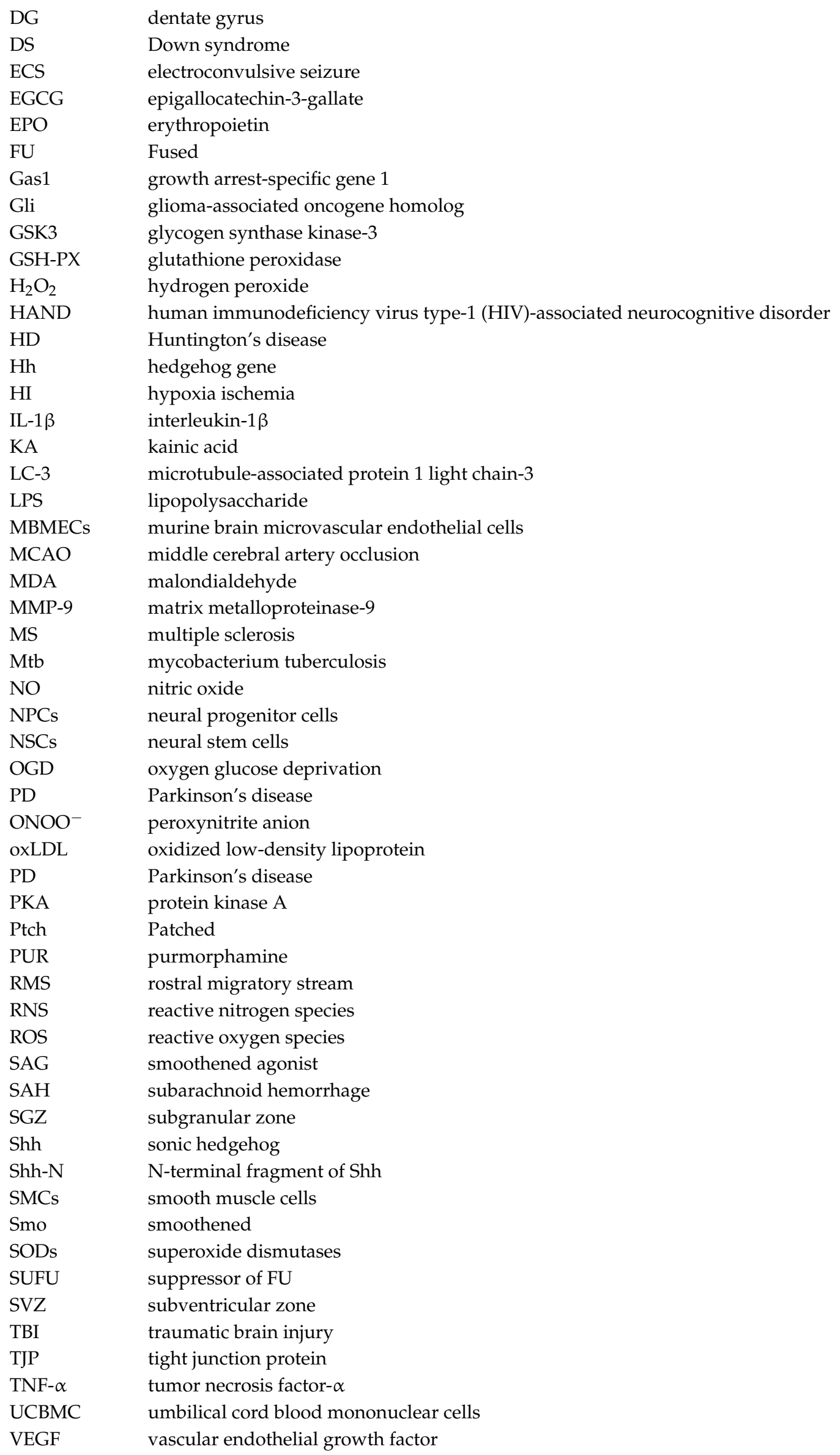




\section{References}

1. Nusslein-Volhard, C.; Wieschaus, E. Mutations affecting segment number and polarity in Drosophila. Nature 1980, 287, 795-801. [CrossRef] [PubMed]

2. Ruiz i Altaba, A.; Palma, V.; Dahmane, N. Hedgehog-Gli signalling and the growth of the brain. Nat. Rev. Neurosci. 2002, 3, 24-33. [CrossRef] [PubMed]

3. Wechsler-Reya, R.J.; Scott, M.P. Control of neuronal precursor proliferation in the cerebellum by Sonic Hedgehog. Neuron 1999, 22, 103-114. [CrossRef]

4. Hynes, M.; Porter, J.A.; Chiang, C.; Chang, D.; Tessier-Lavigne, M.; Beachy, P.A.; Rosenthal, A. Induction of midbrain dopaminergic neurons by Sonic hedgehog. Neuron 1995, 15, 35-44. [CrossRef]

5. Ericson, J.; Muhr, J.; Placzek, M.; Lints, T.; Jessell, T.M.; Edlund, T. Sonic hedgehog induces the differentiation of ventral forebrain neurons: A common signal for ventral patterning within the neural tube. Cell 1995, 81, 747-756. [CrossRef]

6. Echelard, Y.; Epstein, D.J.; St-Jacques, B.; Shen, L.; Mohler, J.; McMahon, J.A.; McMahon, A.P. Sonic hedgehog, a member of a family of putative signaling molecules, is implicated in the regulation of CNS polarity. Cell 1993, 75, 1417-1430. [CrossRef]

7. Fuccillo, M.; Joyner, A.L.; Fishell, G. Morphogen to mitogen: The multiple roles of hedgehog signalling in vertebrate neural development. Nat. Rev. Neurosci. 2006, 7, 772-783. [CrossRef] [PubMed]

8. Xavier, G.M.; Seppala, M.; Barrell, W.; Birjandi, A.A.; Geoghegan, F.; Cobourne, M.T. Hedgehog receptor function during craniofacial development. Dev. Biol. 2016, 415, 198-215. [CrossRef] [PubMed]

9. Ahlgren, S.C.; Bronner-Fraser, M. Inhibition of sonic hedgehog signaling in vivo results in craniofacial neural crest cell death. Curr. Biol. 1999, 9, 1304-1314. [CrossRef]

10. Petryk, A.; Graf, D.; Marcucio, R. Holoprosencephaly: Signaling interactions between the brain and the face, the environment and the genes, and the phenotypic variability in animal models and humans. Wiley Interdiscip. Rev. Dev. Biol. 2015, 4, 17-32. [CrossRef] [PubMed]

11. Marcucio, R.S.; Young, N.M.; Hu, D.; Hallgrimsson, B. Mechanisms that underlie co-variation of the brain and face. Genesis 2011, 49, 177-189. [CrossRef] [PubMed]

12. Chiang, C.; Litingtung, Y.; Lee, E.; Young, K.E.; Corden, J.L.; Westphal, H.; Beachy, P.A. Cyclopia and defective axial patterning in mice lacking Sonic hedgehog gene function. Nature 1996, 383, 407-413. [CrossRef] [PubMed]

13. Tabler, J.M.; Bolger, T.G.; Wallingford, J.; Liu, K.J. Hedgehog activity controls opening of the primary mouth. Dev. Biol. 2014, 396, 1-7. [CrossRef] [PubMed]

14. Yamagishi, C.; Yamagishi, H.; Maeda, J.; Tsuchihashi, T.; Ivey, K.; Hu, T.; Srivastava, D. Sonic hedgehog is essential for first pharyngeal arch development. Pediatr. Res. 2006, 59, 349-354. [CrossRef] [PubMed]

15. Washington Smoak, I.; Byrd, N.A.; Abu-Issa, R.; Goddeeris, M.M.; Anderson, R.; Morris, J.; Yamamura, K.; Klingensmith, J.; Meyers, E.N. Sonic hedgehog is required for cardiac outflow tract and neural crest cell development. Dev. Biol. 2005, 283, 357-372. [CrossRef] [PubMed]

16. Yin, V.T.; Esmaeli, B. Targeting the Hedgehog pathway for locally advanced and metastatic basal cell carcinoma. Curr. Pharm. Des. 2017, 23, 655-659. [PubMed]

17. Samkari, A.; White, J.; Packer, R. SHH inhibitors for the treatment of medulloblastoma. Expert Rev. Neurother. 2015, 15, 763-770. [CrossRef] [PubMed]

18. Laukkanen, M.O.; Castellone, M.D. Hijacking the Hedgehog pathway in cancer therapy. Anticancer Agents Med. Chem. 2016, 16, 309-317. [CrossRef] [PubMed]

19. Gajjar, A.J.; Robinson, G.W. Medulloblastoma-translating discoveries from the bench to the bedside. Nat. Rev. Clin. Oncol. 2014, 11, 714-722. [CrossRef] [PubMed]

20. Gupta, S.; Takebe, N.; Lorusso, P. Targeting the Hedgehog pathway in cancer. Ther. Adv. Med. Oncol. 2010, 2, 237-250. [CrossRef] [PubMed]

21. Goetz, S.C.; Anderson, K.V. The primary cilium: A signalling centre during vertebrate development. Nat. Rev. Genet. 2010, 11, 331-344. [CrossRef] [PubMed]

22. Chen, Y.; Jiang, J. Decoding the phosphorylation code in Hedgehog signal transduction. Cell Res. 2013, 23, 186-200. [CrossRef] [PubMed] 
23. Chen, Y.; Sasai, N.; Ma, G.; Yue, T.; Jia, J.; Briscoe, J.; Jiang, J. Sonic hedgehog dependent phosphorylation by CK1 $\alpha$ and GRK2 is required for ciliary accumulation and activation of smoothened. PLoS Biol. 2011, 9, e1001083. [CrossRef] [PubMed]

24. Rubin, L.L.; de Sauvage, F.J. Targeting the Hedgehog pathway in cancer. Nat. Rev. Drug Discov. 2006, 5, 1026-1033. [CrossRef] [PubMed]

25. Skoda, A.M.; Simovic, D.; Karin, V.; Kardum, V.; Vranic, S.; Serman, L. The role of the Hedgehog signaling pathway in cancer: A comprehensive review. Bosn. J. Basic Med. Sci. 2018, 18, 8-20. [CrossRef] [PubMed]

26. Kenney, A.M.; Cole, M.D.; Rowitch, D.H. Nmyc upregulation by sonic hedgehog signaling promotes proliferation in developing cerebellar granule neuron precursors. Development 2003, 130, 15-28. [CrossRef] [PubMed]

27. Cayuso, J.; Ulloa, F.; Cox, B.; Briscoe, J.; Marti, E. The Sonic hedgehog pathway independently controls the patterning, proliferation and survival of neuroepithelial cells by regulating Gli activity. Development 2006, 133, 517-528. [CrossRef] [PubMed]

28. Regl, G.; Kasper, M.; Schnidar, H.; Eichberger, T.; Neill, G.W.; Philpott, M.P.; Esterbauer, H.; Hauser-Kronberger, C.; Frischauf, A.M.; Aberger, F. Activation of the BCL2 promoter in response to Hedgehog/GLI signal transduction is predominantly mediated by GLI2. Cancer Res. 2004, 64, 7724-7731. [CrossRef] [PubMed]

29. Leung, C.; Lingbeek, M.; Shakhova, O.; Liu, J.; Tanger, E.; Saremaslani, P.; Van Lohuizen, M.; Marino, S. Bmi1 is essential for cerebellar development and is overexpressed in human medulloblastomas. Nature 2004, 428, 337-341. [CrossRef] [PubMed]

30. Alvarez-Buylla, A.; Ihrie, R.A. Sonic hedgehog signaling in the postnatal brain. Semin. Cell Dev. Biol. 2014, 33, 105-111. [CrossRef] [PubMed]

31. Lai, K.; Kaspar, B.K.; Gage, F.H.; Schaffer, D.V. Sonic hedgehog regulates adult neural progenitor proliferation in vitro and in vivo. Nat. Neurosci. 2003, 6, 21-27. [CrossRef] [PubMed]

32. Yao, P.J.; Petralia, R.S.; Mattson, M.P. Sonic hedgehog signaling and hippocampal neuroplasticity. Trends Neurosci. 2016, 39, 840-850. [CrossRef] [PubMed]

33. Dashti, M.; Peppelenbosch, M.P.; Rezaee, F. Hedgehog signalling as an antagonist of ageing and its associated diseases. Bioessays 2012, 34, 849-856. [CrossRef] [PubMed]

34. Han, Y.G.; Spassky, N.; Romaguera-Ros, M.; Garcia-Verdugo, J.M.; Aguilar, A.; Schneider-Maunoury, S.; Alvarez-Buylla, A. Hedgehog signaling and primary cilia are required for the formation of adult neural stem cells. Nat. Neurosci. 2008, 11, 277-284. [CrossRef] [PubMed]

35. Traiffort, E.; Charytoniuk, D.A.; Faure, H.; Ruat, M. Regional distribution of Sonic Hedgehog, patched, and smoothened mRNA in the adult rat brain. J. Neurochem. 1998, 70, 1327-1330. [CrossRef] [PubMed]

36. Ji, H.; Miao, J.; Zhang, X.; Du, Y.; Liu, H.; Li, S.; Li, L. Inhibition of sonic hedgehog signaling aggravates brain damage associated with the down-regulation of Gli1, Ptch1 and SOD1 expression in acute ischemic stroke. Neurosci. Lett. 2012, 506, 1-6. [CrossRef] [PubMed]

37. Amankulor, N.M.; Hambardzumyan, D.; Pyonteck, S.M.; Becher, O.J.; Joyce, J.A.; Holland, E.C. Sonic hedgehog pathway activation is induced by acute brain injury and regulated by injury-related inflammation. J. Neurosci. 2009, 29, 10299-10308. [CrossRef] [PubMed]

38. Hung, Y.H.; Chang, S.H.; Huang, C.T.; Yin, J.H.; Hwang, C.S.; Yang, L.Y.; Yang, D.I. Inhibitor of differentiation-1 and hypoxia-inducible factor-1 mediate sonic hedgehog induction by amyloid $\beta$-peptide in rat cortical neurons. Mol. Neurobiol. 2016, 53, 793-809. [CrossRef] [PubMed]

39. Pitter, K.L.; Tamagno, I.; Feng, X.; Ghosal, K.; Amankulor, N.; Holland, E.C.; Hambardzumyan, D. The $\mathrm{SHH} /$ Gli pathway is reactivated in reactive glia and drives proliferation in response to neurodegenerationinduced lesions. Glia 2014, 62, 1595-1607. [CrossRef] [PubMed]

40. Xia, Y.P.; Dai, R.L.; Li, Y.N.; Mao, L.; Xue, Y.M.; He, Q.W.; Huang, M.; Huang, Y.; Mei, Y.W.; Hu, B. The protective effect of sonic hedgehog is mediated by the phosphoinositide 3-kinase/AKT/Bcl-2 pathway in cultured rat astrocytes under oxidative stress. Neuroscience 2012, 209, 1-11. [CrossRef] [PubMed]

41. Becher, O.J.; Hambardzumyan, D.; Fomchenko, E.I.; Momota, H.; Mainwaring, L.; Bleau, A.M.; Katz, A.M.; Edgar, M.; Kenney, A.M.; Cordon-Cardo, C. Gli activity correlates with tumor grade in platelet-derived growth factor-induced gliomas. Cancer Res. 2008, 68, 2241-2249. [CrossRef] [PubMed]

42. Chen, S.D.; Wu, C.L.; Hwang, W.C.; Yang, D.I. More insight into BDNF against neurodegeneration: Anti-apoptosis, anti-oxidation, and suppression of autophagy. Int. J. Mol. Sci. 2017, 18, 545. [CrossRef] [PubMed] 
43. Madhavan, L.; Daley, B.F.; Davidson, B.L.; Boudreau, R.L.; Lipton, J.W.; Cole-Strauss, A.; Steece-Collier, K.; Collier, T.J. Sonic hedgehog controls the phenotypic fate and therapeutic efficacy of grafted neural precursor cells in a model of nigrostriatal neurodegeneration. PLoS ONE 2015, 10, e0137136. [CrossRef] [PubMed]

44. Zhang, Y.; Dong, W.; Guo, S.; Zhao, S.; He, S.; Zhang, L.; Tang, Y.; Wang, H. Lentivirus-mediated delivery of sonic hedgehog into the striatum stimulates neuroregeneration in a rat model of Parkinson disease. Neurol. Sci. 2014, 35, 1931-1940. [CrossRef] [PubMed]

45. Huang, S.S.; Cheng, H.; Tang, C.M.; Nien, M.W.; Huang, Y.S.; Lee, I.H.; Yin, J.H.; Kuo, T.B.; Yang, C.C.; Tsai, S.K.; et al. Anti-oxidative, anti-apoptotic, and pro-angiogenic effects mediate functional improvement by sonic hedgehog against focal cerebral ischemia in rats. Exp. Neurol. 2013, 247, 680-688. [CrossRef] [PubMed]

46. Wu, C.L.; Chen, S.D.; Yin, J.H.; Hwang, C.S.; Yang, D.I. Erythropoietin and sonic hedgehog mediate the neuroprotective effects of brain-derived neurotrophic factor against mitochondrial inhibition. Neurobiol. Dis. 2010, 40, 146-154. [CrossRef] [PubMed]

47. Wu, C.L.; Chen, S.D.; Hwang, C.S.; Yang, D.I. Sonic hedgehog mediates BDNF-induced neuroprotection against mitochondrial inhibitor 3-nitropropionic acid. Biochem. Biophys. Res. Commun. 2009, 385, 112-117. [CrossRef] [PubMed]

48. Suwelack, D.; Hurtado-Lorenzo, A.; Millan, E.; Gonzalez-Nicolini, V.; Wawrowsky, K.; Lowenstein, P.R.; Castro, M.G. Neuronal expression of the transcription factor Gli1 using the T $\alpha 1 \alpha$-tubulin promoter is neuroprotective in an experimental model of Parkinson's disease. Gene Ther. 2004, 11, 1742-1752. [CrossRef] [PubMed]

49. Wu, C.L.; Hwang, C.S.; Chen, S.D.; Yin, J.H.; Yang, D.I. Neuroprotective mechanisms of brain-derived neurotrophic factor against 3-nitropropionic acid toxicity: Therapeutic implications for Huntington's disease. Ann. N. Y. Acad. Sci. 2010, 1201, 8-12. [CrossRef] [PubMed]

50. Zhang, L.; Chopp, M.; Meier, D.H.; Winter, S.; Wang, L.; Szalad, A.; Lu, M.; Wei, M.; Cui, Y.; Zhang, Z.G.; et al. Sonic hedgehog signaling pathway mediates cerebrolysin-improved neurological function after stroke. Stroke 2013, 44, 1965-1972. [CrossRef] [PubMed]

51. Ding, X.; Li, Y.; Liu, Z.; Zhang, J.; Cui, Y.; Chen, X.; Chopp, M. The sonic hedgehog pathway mediates brain plasticity and subsequent functional recovery after bone marrow stromal cell treatment of stroke in mice. J. Cereb. Blood Flow Metab. 2013, 33, 1015-1024. [CrossRef] [PubMed]

52. Sims, J.R.; Lee, S.W.; Topalkara, K.; Qiu, J.; Xu, J.; Zhou, Z.; Moskowitz, M.A. Sonic hedgehog regulates ischemia/hypoxia-induced neural progenitor proliferation. Stroke 2009, 40, 3618-3626. [CrossRef] [PubMed]

53. Yao, P.J.; Manor, U.; Petralia, R.S.; Brose, R.D.; Wu, R.T.; Ott, C.; Wang, Y.X.; Charnoff, A.; Lippincott-Schwartz, J.; Mattson, M.P. Sonic hedgehog pathway activation increases mitochondrial abundance and activity in hippocampal neurons. Mol. Biol. Cell 2017, 28, 387-395. [CrossRef] [PubMed]

54. Lauth, M. Sonic the Hedgehog: A game about aging? Emerging evidence for anti-geriatric effects of Hedgehog signaling. Bioessays 2014, 36, 1128. [PubMed]

55. Renault, M.A.; Robbesyn, F.; Chapouly, C.; Yao, Q.; Vandierdonck, S.; Reynaud, A.; Belloc, I.; Traiffort, E.; Ruat, M.; Desgranges, C.; et al. Hedgehog-dependent regulation of angiogenesis and myogenesis is impaired in aged mice. Arterioscler. Thromb. Vasc. Biol. 2013, 33, 2858-2866. [CrossRef] [PubMed]

56. Bishop, C.L.; Bergin, A.M.; Fessart, D.; Borgdorff, V.; Hatzimasoura, E.; Garbe, J.C.; Stampfer, M.R.; Koh, J.; Beach, D.H. Primary cilium-dependent and -independent Hedgehog signaling inhibits p16(INK4A). Mol. Cell 2010, 40, 533-547. [CrossRef] [PubMed]

57. Teperino, R.; Amann, S.; Bayer, M.; McGee, S.L.; Loipetzberger, A.; Connor, T.; Jaeger, C.; Kammerer, B.; Winter, L.; Wiche, G.; et al. Hedgehog partial agonism drives Warburg-like metabolism in muscle and brown fat. Cell 2012, 151, 414-426. [CrossRef] [PubMed]

58. Kempermann, G.; Song, H.; Gage, F.H. Neurogenesis in the adult hippocampus. Cold Spring Harb. Perspect. Biol. 2015, 7, a018812. [CrossRef] [PubMed]

59. Sakalem, M.E.; Seidenbecher, T.; Zhang, M.; Saffari, R.; Kravchenko, M.; Wordemann, S.; Diederich, K.; Schwamborn, J.C.; Zhang, W.; Ambrée, O. Environmental enrichment and physical exercise revert behavioral and electrophysiological impairments caused by reduced adult neurogenesis. Hippocampus 2017, 27, 36-51. [CrossRef] [PubMed]

60. Winner, B.; Winkler, J. Adult neurogenesis in neurodegenerative diseases. Cold Spring Harb. Perspect. Biol. 2015, 7, a021287. [CrossRef] [PubMed] 
61. Seib, D.R.; Martin-Villalba, A. Neurogenesis in the normal ageing hippocampus: A mini-review. Gerontology 2015, 61, 327-335. [CrossRef] [PubMed]

62. Wakabayashi, T.; Hidaka, R.; Fujimaki, S.; Asashima, M.; Kuwabara, T. MicroRNAs and epigenetics in adult neurogenesis. Adv. Genet. 2014, 86, 27-44. [PubMed]

63. Jessberger, S.; Parent, J.M. Epilepsy and adult neurogenesis. Cold Spring Harb. Perspect. Biol. 2015, 7, a020677. [CrossRef] [PubMed]

64. Matsuda, T.; Murao, N.; Katano, Y.; Juliandi, B.; Kohyama, J.; Akira, S.; Kawai, T.; Nakashima, K. TLR9 signalling in microglia attenuates seizure-induced aberrant neurogenesis in the adult hippocampus. Nat. Commun. 2015, 6, 6514. [CrossRef] [PubMed]

65. Kokaia, M. Seizure-induced neurogenesis in the adult brain. Eur. J. Neurosci. 2011, 33, 1133-1138. [CrossRef] [PubMed]

66. Lindvall, O.; Kokaia, Z. Neurogenesis following stroke affecting the adult brain. Cold Spring Harb. Perspect. Biol. 2015, 7, a019034. [CrossRef] [PubMed]

67. Lin, R.; Cai, J.; Nathan, C.; Wei, X.; Schleidt, S.; Rosenwasser, R.; Iacovitti, L. Neurogenesis is enhanced by stroke in multiple new stem cell niches along the ventricular system at sites of high BBB permeability. Neurobiol. Dis. 2015, 74, 229-239. [CrossRef] [PubMed]

68. Zhang, R.L.; Chopp, M.; Roberts, C.; Liu, X.; Wei, M.; Nejad-Davarani, S.P.; Wang, X.; Zhang, Z.G. Stroke increases neural stem cells and angiogenesis in the neurogenic niche of the adult mouse. PLoS ONE 2014, 9, e113972. [CrossRef] [PubMed]

69. Charron, F.; Tessier-Lavigne, M. The Hedgehog, TGF- $\beta$ /BMP and Wnt families of morphogens in axon guidance. Adv. Exp. Med. Biol. 2007, 621, 116-133. [PubMed]

70. Yam, P.T.; Charron, F. Signaling mechanisms of non-conventional axon guidance cues: The Shh, BMP and Wnt morphogens. Curr. Opin. Neurobiol. 2013, 23, 965-973. [CrossRef] [PubMed]

71. Choy, S.W.; Cheng, S.H. Hedgehog signaling. Vitam. Horm. 2012, 88, 1-23. [PubMed]

72. Zhang, Y.; Zhang, X.; Cui, L.; Chen, R.; Zhang, C.; Li, Y.; He, T.; Zhu, X.; Shen, Z.; Dong, L.; et al. Salvianolic Acids for Injection (SAFI) promotes functional recovery and neurogenesis via sonic hedgehog pathway after stroke in mice. Neurochem. Int. 2017, 110, 38-48. [CrossRef] [PubMed]

73. Lopez, M.S.; Dempsey, R.J.; Vemuganti, R. Resveratrol neuroprotection in stroke and traumatic CNS injury. Neurochem. Int. 2015, 89, 75-82. [CrossRef] [PubMed]

74. Bastianetto, S.; Menard, C.; Quirion, R. Neuroprotective action of resveratrol. Biochim. Biophys. Acta 2015, 1852, 1195-1201. [CrossRef] [PubMed]

75. Singh, N.; Agrawal, M.; Dore, S. Neuroprotective properties and mechanisms of resveratrol in in vitro and in vivo experimental cerebral stroke models. ACS Chem. Neurosci. 2013, 4, 1151-1162. [CrossRef] [PubMed]

76. Yu, P.; Wang, L.; Tang, F.; Zeng, L.; Zhou, L.; Song, X.; Jia, W.; Chen, J.; Yang, Q. Resveratrol pretreatment decreases ischemic injury and improves neurological function via Sonic hedgehog signaling after stroke in rats. Mol. Neurobiol. 2017, 54, 212-226. [CrossRef] [PubMed]

77. Schneider, C.; Segre, T. Green tea: Potential health benefits. Am. Fam. Phys. 2009, 79, 591-594.

78. Kuriyama, S.; Shimazu, T.; Ohmori, K.; Kikuchi, N.; Nakaya, N.; Nishino, Y.; Tsubono, Y.; Tsuji, I. Green tea consumption and mortality due to cardiovascular disease, cancer, and all causes in Japan: The Ohsaki study. JAMA 2006, 296, 1255-1265. [CrossRef] [PubMed]

79. Wang, Y.; Li, M.; Xu, X.; Song, M.; Tao, H.; Bai, Y. Green tea epigallocatechin-3-gallate (EGCG) promotes neural progenitor cell proliferation and sonic hedgehog pathway activation during adult hippocampal neurogenesis. Mol. Nutr. Food Res. 2012, 56, 1292-1303. [CrossRef] [PubMed]

80. Chen, J.K.; Taipale, J.; Cooper, M.K.; Beachy, P.A. Inhibition of Hedgehog signaling by direct binding of cyclopamine to Smoothened. Genes Dev. 2002, 16, 2743-2748. [CrossRef] [PubMed]

81. Frank-Kamenetsky, M.; Zhang, X.M.; Bottega, S.; Guicherit, O.; Wichterle, H.; Dudek, H.; Bumcrot, D.; Wang, F.Y.; Jones, S.; Shulok, J.; et al. Small-molecule modulators of Hedgehog signaling: Identification and characterization of Smoothened agonists and antagonists. J. Biol. 2002, 1, 10. [CrossRef] [PubMed]

82. Jin, Y.; Barnett, A.; Zhang, Y.; Yu, X.; Luo, Y. Poststroke Sonic hedgehog agonist treatment improves functional recovery by enhancing neurogenesis and angiogenesis. Stroke 2017, 48, 1636-1645. [CrossRef] [PubMed]

83. Dierssen, M. Down syndrome: The brain in trisomic mode. Nat. Rev. Neurosci. 2012, 13, 844-858. [CrossRef] [PubMed] 
84. Bartesaghi, R.; Guidi, S.; Ciani, E. Is it possible to improve neurodevelopmental abnormalities in Down syndrome? Rev. Neurosci. 2011, 22, 419-455. [CrossRef] [PubMed]

85. Trazzi, S.; Fuchs, C.; Valli, E.; Perini, G.; Bartesaghi, R.; Ciani, E. The amyloid precursor protein (APP) triplicated gene impairs neuronal precursor differentiation and neurite development through two different domains in the Ts65Dn mouse model for Down syndrome. J. Biol. Chem. 2013, 288, 20817-20829. [CrossRef] [PubMed]

86. Trazzi, S.; Mitrugno, V.M.; Valli, E.; Fuchs, C.; Rizzi, S.; Guidi, S.; Perini, G.; Bartesaghi, R.; Ciani, E. APP-dependent up-regulation of Ptch1 underlies proliferation impairment of neural precursors in Down syndrome. Hum. Mol. Genet. 2011, 20, 1560-1573. [CrossRef] [PubMed]

87. Giacomini, A.; Stagni, F.; Trazzi, S.; Guidi, S.; Emili, M.; Brigham, E.; Ciani, E.; Bartesaghi, R. Inhibition of APP gamma-secretase restores Sonic Hedgehog signaling and neurogenesis in the Ts65Dn mouse model of Down syndrome. Neurobiol. Dis. 2015, 82, 385-396. [CrossRef] [PubMed]

88. Stagni, F.; Raspanti, A.; Giacomini, A.; Guidi, S.; Emili, M.; Ciani, E.; Giuliani, A.; Bighinati, A.; Calzà, L.; Magistretti, J.; et al. Long-term effect of neonatal inhibition of APP gamma-secretase on hippocampal development in the Ts65Dn mouse model of Down syndrome. Neurobiol. Dis. 2017, 103, 11-23. [CrossRef] [PubMed]

89. Das, I.; Park, J.M.; Shin, J.H.; Jeon, S.K.; Lorenzi, H.; Linden, D.J.; Worley, P.F.; Reeves, R.H. Hedgehog agonist therapy corrects structural and cognitive deficits in a Down syndrome mouse model. Sci. Transl. Med. 2013, 5, 201ra120. [CrossRef] [PubMed]

90. Zhang, C.; Chopp, M.; Cui, Y.; Wang, L.; Zhang, R.; Zhang, L.; Lu, M.; Szalad, A.; Doppler, E.; Hitzl, M. Cerebrolysin enhances neurogenesis in the ischemic brain and improves functional outcome after stroke. J. Neurosci. Res. 2010, 88, 3275-3281. [CrossRef] [PubMed]

91. Alvarez, X.A.; Cacabelos, R.; Sampedro, C.; Aleixandre, M.; Linares, C.; Granizo, E.; Doppler, E.; Moessler, H. Efficacy and safety of Cerebrolysin in moderate to moderately severe Alzheimer's disease: Results of a randomized, double-blind, controlled trial investigating three dosages of Cerebrolysin. Eur. J. Neurol. 2011, 18, 59-68. [CrossRef] [PubMed]

92. Bambakidis, N.C.; Petrullis, M.; Kui, X.; Rothstein, B.; Karampelas, I.; Kuang, Y.; Selman, W.R.; LaManna, J.C.; Miller, R.H. Improvement of neurological recovery and stimulation of neural progenitor cell proliferation by intrathecal administration of Sonic hedgehog. J. Neurosurg. 2012, 116, 1114-1120. [CrossRef] [PubMed]

93. Lipsman, N.; Sankar, T.; Downar, J.; Kennedy, S.H.; Lozano, A.M.; Giacobbe, P. Neuromodulation for treatment-refractory major depressive disorder. CMAJ 2014, 186, 33-39. [CrossRef] [PubMed]

94. Madsen, T.M.; Treschow, A.; Bengzon, J.; Bolwig, T.G.; Lindvall, O.; Tingstrom, A. Increased neurogenesis in a model of electroconvulsive therapy. Biol. Psychiatry 2000, 47, 1043-1049. [CrossRef]

95. Malberg, J.E.; Eisch, A.J.; Nestler, E.J.; Duman, R.S. Chronic antidepressant treatment increases neurogenesis in adult rat hippocampus. J. Neurosci. 2000, 20, 9104-9110. [CrossRef] [PubMed]

96. Vaidya, V.A.; Siuciak, J.A.; Du, F.; Duman, R.S. Hippocampal mossy fiber sprouting induced by chronic electroconvulsive seizures. Neuroscience 1999, 89, 157-166. [CrossRef]

97. Banerjee, S.B.; Rajendran, R.; Dias, B.G.; Ladiwala, U.; Tole, S.; Vaidya, V.A. Recruitment of the sonic hedgehog signalling cascade in electroconvulsive seizure-mediated regulation of adult rat hippocampal neurogenesis. Eur. J. Neurosci. 2005, 22, 1570-1580. [CrossRef] [PubMed]

98. Ahmed, A.I.; Shtaya, A.B.; Zaben, M.J.; Owens, E.V.; Kiecker, C.; Gray, W.P. Endogenous GFAP-positive neural stem/progenitor cells in the postnatal mouse cortex are activated following traumatic brain injury. J. Neurotrauma 2012, 29, 828-842. [CrossRef] [PubMed]

99. Sreenivasmurthy, S.G.; Liu, J.Y.; Song, J.X.; Yang, C.B.; Malampati, S.; Wang, Z.Y.; Huang, Y.Y.; Li, M. Neurogenic traditional Chinese medicine as a promising strategy for the treatment of Alzheimer's disease. Int. J. Mol. Sci. 2017, 18, 272. [CrossRef] [PubMed]

100. He, P.; Staufenbiel, M.; Li, R.; Shen, Y. Deficiency of patched 1-induced Gli1 signal transduction results in astrogenesis in Swedish mutated APP transgenic mice. Hum. Mol. Genet. 2014, 23, 6512-6527. [CrossRef] [PubMed]

101. Chen, S.D.; Zhen, Y.Y.; Lin, J.W.; Lin, T.K.; Huang, C.W.; Liou, C.W.; Chan, S.H.; Chuang, Y.C. Dynamin-related protein 1 promotes mitochondrial fission and contributes to the hippocampal neuronal cell death following experimental status epilepticus. CNS Neurosci. Ther. 2016, 22, 988-999. [CrossRef] [PubMed] 
102. Pollard, H.; Charriaut-Marlangue, C.; Cantagrel, S.; Represa, A.; Robain, O.; Moreau, J.; Ben-Ari, Y. Kainate-induced apoptotic cell death in hippocampal neurons. Neuroscience 1994, 63, 7-18. [CrossRef]

103. Geissler, M.; Dinse, H.R.; Neuhoff, S.; Kreikemeier, K.; Meier, C. Human umbilical cord blood cells restore brain damage induced changes in rat somatosensory cortex. PLoS ONE 2011, 6, e20194. [CrossRef] [PubMed]

104. Xia, G.; Hong, X.; Chen, X.; Lan, F.; Zhang, G.; Liao, L. Intracerebral transplantation of mesenchymal stem cells derived from human umbilical cord blood alleviates hypoxic ischemic brain injury in rat neonates. J. Perinat. Med. 2010, 38, 215-221. [CrossRef] [PubMed]

105. Gornicka-Pawlak el, B.; Janowski, M.; Habich, A.; Jablonska, A.; Drela, K.; Kozlowska, H.; Lukomska, B.; Sypecka, J.; Domanska-Janik, K. Systemic treatment of focal brain injury in the rat by human umbilical cord blood cells being at different level of neural commitment. Acta Neurobiol. Exp. (Wars) 2011, 71, 46-64. [PubMed]

106. Wang, X.; Zhao, Y.; Wang, X. Umbilical cord blood cells regulate the differentiation of endogenous neural stem cells in hypoxic ischemic neonatal rats via the hedgehog signaling pathway. Brain Res. 2014, 1560, 18-26. [CrossRef] [PubMed]

107. Dan Dunn, J.; Alvarez, L.A.; Zhang, X.; Soldati, T. Reactive oxygen species and mitochondria: A nexus of cellular homeostasis. Redox Biol. 2015, 6, 472-485. [CrossRef] [PubMed]

108. Bae, Y.S.; Oh, H.; Rhee, S.G.; Yoo, Y.D. Regulation of reactive oxygen species generation in cell signaling. Mol. Cells 2011, 32, 491-509. [CrossRef] [PubMed]

109. Novo, E.; Parola, M. The role of redox mechanisms in hepatic chronic wound healing and fibrogenesis. Fibrogen. Tissue Repair 2012, 5, S4. [CrossRef] [PubMed]

110. Niizuma, K.; Yoshioka, H.; Chen, H.; Kim, G.S.; Jung, J.E.; Katsu, M.; Okami, N.; Chan, P.H. Mitochondrial and apoptotic neuronal death signaling pathways in cerebral ischemia. Biochim. Biophys. Acta 2010, 1802, 92-99. [CrossRef] [PubMed]

111. Bayir, H.; Kagan, V.E. Bench-to-bedside review: Mitochondrial injury, oxidative stress and apoptosis-there is nothing more practical than a good theory. Crit. Care 2008, 12, 206. [CrossRef] [PubMed]

112. Chen, S.D.; Wu, H.Y.; Yang, D.I.; Lee, S.Y.; Shaw, F.Z.; Lin, T.K.; Liou, C.W.; Chuang, Y.C. Effects of rosiglitazone on global ischemia-induced hippocampal injury and expression of mitochondrial uncoupling protein 2. Biochem. Biophys. Res. Commun. 2006, 351, 198-203. [CrossRef] [PubMed]

113. Chen, S.D.; Lin, T.K.; Yang, D.I.; Lee, S.Y.; Shaw, F.Z.; Liou, C.W.; Chuang, Y.C. Protective effects of peroxisome proliferator-activated receptors gamma coactivator- $1 \alpha$ against neuronal cell death in the hippocampal CA1 subfield after transient global ischemia. J. Neurosci. Res. 2010, 88, 605-613. [CrossRef] [PubMed]

114. Balaban, R.S.; Nemoto, S.; Finkel, T. Mitochondria, oxidants, and aging. Cell 2005, 120, 483-495. [CrossRef] [PubMed]

115. Patel, M. Mitochondrial dysfunction and oxidative stress: Cause and consequence of epileptic seizures. Free Radic. Biol. Med. 2004, 37, 1951-1962. [CrossRef] [PubMed]

116. Leonard, J.V.; Schapira, A.H. Mitochondrial respiratory chain disorders II: Neurodegenerative disorders and nuclear gene defects. Lancet 2000, 355, 389-394. [CrossRef]

117. Dai, R.L.; Zhu, S.Y.; Xia, Y.P.; Mao, L.; Mei, Y.W.; Yao, Y.F.; Xue, Y.M.; Hu, B. Sonic hedgehog protects cortical neurons against oxidative stress. Neurochem. Res. 2011, 36, 67-75. [CrossRef] [PubMed]

118. Dai, R.; Xia, Y.; Mao, L.; Mei, Y.; Xue, Y.; Hu, B. Involvement of PI3K/Akt pathway in the neuroprotective effect of Sonic hedgehog on cortical neurons under oxidative stress. J. Huazhong Univ. Sci. Technol. Med. Sci. 2012, 32, 856-860. [CrossRef] [PubMed]

119. He, W.; Cui, L.; Zhang, C.; Zhang, X.; He, J.; Xie, Y.; Chen, Y. Sonic hedgehog promotes neurite outgrowth of cortical neurons under oxidative stress: Involving of mitochondria and energy metabolism. Exp. Cell Res. 2017, 350, 83-90. [CrossRef] [PubMed]

120. Li, T.; Zhang, J.; Liu, R.Y.; Lian, Z.G.; Chen, X.L.; Ma, L.; Sun, H.M.; Zhao, Y.L. The role of the sonic hedgehog signaling pathway in early brain injury after experimental subarachnoid hemorrhage in rats. Neurosci. Lett. 2013, 552, 81-86. [CrossRef] [PubMed]

121. Hu, Q.; Li, T.; Wang, L.; Xie, Y.; Liu, S.; Bai, X.; Zhang, T.; Bo, S.; Xin, D.; Xue, H.; et al. Neuroprotective effects of a Smoothened receptor agonist against early brain injury after experimental subarachnoid hemorrhage in rats. Front. Cell. Neurosci. 2016, 10, 306. [CrossRef] [PubMed]

122. Volkmar, F.R.; Lord, C.; Bailey, A.; Schultz, R.T.; Klin, A. Autism and pervasive developmental disorders. J. Child Psychol. Psychiatry 2004, 45, 135-170. [CrossRef] [PubMed] 
123. Chauhan, A.; Chauhan, V. Oxidative stress in autism. Pathophysiology 2006, 13, 171-181. [CrossRef] [PubMed]

124. Al-Ayadhi, L.Y. Relationship between sonic hedgehog protein, brain-derived neurotrophic factor and oxidative stress in autism spectrum disorders. Neurochem. Res. 2012, 37, 394-400. [CrossRef] [PubMed]

125. Li, D.; Mehta, J.L. Antisense to LOX-1 inhibits oxidized LDL-mediated upregulation of monocyte chemoattractant protein-1 and monocyte adhesion to human coronary artery endothelial cells. Circulation 2000, 101, 2889-2895. [CrossRef] [PubMed]

126. Schreurs, M.P.; Cipolla, M.J. Cerebrovascular dysfunction and blood-brain barrier permeability induced by oxidized LDL are prevented by apocynin and magnesium sulfate in female rats. J. Cardiovasc. Pharmacol. 2014, 63, 33-39. [CrossRef] [PubMed]

127. Sweeney, M.D.; Sagare, A.P.; Zlokovic, B.V. Blood-brain barrier breakdown in Alzheimer disease and other neurodegenerative disorders. Nat. Rev. Neurol. 2018, 14, 133-150. [CrossRef] [PubMed]

128. Jiang, X.L.; Chen, T.; Zhang, X. Activation of sonic hedgehog signaling attenuates oxidized low-density lipoprotein-stimulated brain microvascular endothelial cells dysfunction in vitro. Int. J. Clin. Exp. Pathol. 2015, 8, 12820-12828. [PubMed]

129. Chen, K.Y.; Chiu, C.H.; Wang, L.C. Anti-apoptotic effects of Sonic hedgehog signalling through oxidative stress reduction in astrocytes co-cultured with excretory-secretory products of larval Angiostrongylus cantonensis. Sci. Rep. 2017, 7, 41574. [CrossRef] [PubMed]

130. Peterson, R.; Turnbull, J. Sonic hedgehog is cytoprotective against oxidative challenge in a cellular model of amyotrophic lateral sclerosis. J. Mol. Neurosci. 2012, 47, 31-41. [CrossRef] [PubMed]

131. Stephenson, J.; Nutma, E.; van der Valk, P.; Amor, S. Inflammation in CNS neurodegenerative diseases. Immunology 2018, 154, 204-219. [CrossRef] [PubMed]

132. Chitnis, T.; Weiner, H.L. CNS inflammation and neurodegeneration. J. Clin. Investig. 2017, 127, 3577-3587. [CrossRef] [PubMed]

133. Brown, G.C.; Neher, J.J. Inflammatory neurodegeneration and mechanisms of microglial killing of neurons. Mol. Neurobiol. 2010, 41, 242-247. [CrossRef] [PubMed]

134. Daneman, R.; Prat, A. The blood-brain barrier. Cold Spring Harb. Perspect. Biol. 2015, 7, a020412. [CrossRef] [PubMed]

135. Abbott, N.J.; Ronnback, L.; Hansson, E. Astrocyte-endothelial interactions at the blood-brain barrier. Nat. Rev. Neurosci. 2006, 7, 41-53. [CrossRef] [PubMed]

136. Brilha, S.; Ong, C.W.M.; Weksler, B.; Romero, N.; Couraud, P.O.; Friedland, J.S. Matrix metalloproteinase-9 activity and a downregulated Hedgehog pathway impair blood-brain barrier function in an in vitro model of CNS tuberculosis. Sci. Rep. 2017, 7, 16031. [CrossRef] [PubMed]

137. Zhen, H.; Zhao, L.; Ling, Z.; Kuo, L.; Xue, X.; Feng, J. Wip1 regulates blood-brain barrier function and neuro-inflammation induced by lipopolysaccharide via the sonic hedgehog signaling signaling pathway. Mol. Immunol. 2018, 93, 31-37. [CrossRef] [PubMed]

138. Singh, V.B.; Singh, M.V.; Piekna-Przybylska, D.; Gorantla, S.; Poluektova, L.Y.; Maggirwar, S.B. Sonic Hedgehog mimetic prevents leukocyte infiltration into the CNS during acute HIV infection. Sci. Rep. 2017, 7, 9578. [CrossRef] [PubMed]

139. Singh, V.B.; Singh, M.V.; Gorantla, S.; Poluektova, L.Y.; Maggirwar, S.B. Smoothened agonist reduces human immunodeficiency virus type-1-induced blood-brain barrier breakdown in humanized mice. Sci. Rep. 2016, 6, 26876. [CrossRef] [PubMed]

140. Alvarez, J.I.; Dodelet-Devillers, A.; Kebir, H.; Ifergan, I.; Fabre, P.J.; Terouz, S.; Sabbagh, M.; Wosik, K.; Bourbonnière, L.; Bernard, M.; et al. The hedgehog pathway promotes blood-brain barrier integrity and CNS immune quiescence. Science 2011, 334, 1727-1731. [CrossRef] [PubMed]

141. Wang, Y.; Jin, S.; Sonobe, Y.; Cheng, Y.; Horiuchi, H.; Parajuli, B.; Kawanokuchi, J.; Mizuno, T.; Takeuchi, H.; Suzumura, A. Interleukin-1 $\beta$ induces blood-brain barrier disruption by downregulating Sonic hedgehog in astrocytes. PLoS ONE 2014, 9, e110024. [CrossRef] [PubMed]

142. Shen, X.F.; Zhao, Y.; Jiang, J.P.; Guan, W.X.; Du, J.F. Phosphatase Wip1 in immunity: An overview and update. Front. Immunol. 2017, 8, 8. [CrossRef] [PubMed]

143. Zhong, H.; Cui, L.; Xu, F.; Chen, L.; Jiang, L.; Huang, H.; Xu, J.; Zhao, X.; Li, L.; Zeng, S.; et al. Up-regulation of Wip1 involves in neuroinflammation of retinal astrocytes after optic nerve crush via NF- $\mathrm{B}$ signaling pathway. Inflamm. Res. 2016, 65, 709-715. [CrossRef] [PubMed] 
144. Lowe, J.; Cha, H.; Lee, M.O.; Mazur, S.J.; Appella, E.; Fornace, A.J., Jr. Regulation of the Wip1 phosphatase and its effects on the stress response. Front. Biosci. 2012, 17, 1480-1498. [CrossRef]

145. Macurek, L.; Lindqvist, A.; Voets, O.; Kool, J.; Vos, H.R.; Medema, R.H. Wip1 phosphatase is associated with chromatin and dephosphorylates gammaH2AX to promote checkpoint inhibition. Oncogene 2010, 29, 2281-2291. [CrossRef] [PubMed]

146. Lu, X.; Nguyen, T.A.; Moon, S.H.; Darlington, Y.; Sommer, M.; Donehower, L.A. The type 2C phosphatase Wip1: An oncogenic regulator of tumor suppressor and DNA damage response pathways. Cancer Metast. Rev. 2008, 27, 123-135. [CrossRef] [PubMed]

147. Wen, J.; Lee, J.; Malhotra, A.; Nahta, R.; Arnold, A.R.; Buss, M.C.; Brown, B.D.; Maier, C.; Kenney, A.M.; Remke, M.; et al. WIP1 modulates responsiveness to Sonic Hedgehog signaling in neuronal precursor cells and medulloblastoma. Oncogene 2016, 35, 5552-5564. [CrossRef] [PubMed]

148. Rosenberg, G.A.; Yang, Y. Vasogenic edema due to tight junction disruption by matrix metalloproteinases in cerebral ischemia. Neurosurg. Focus 2007, 22, E4. [CrossRef] [PubMed]

149. Yang, Y.; Estrada, E.Y.; Thompson, J.F.; Liu, W.; Rosenberg, G.A. Matrix metalloproteinase-mediated disruption of tight junction proteins in cerebral vessels is reversed by synthetic matrix metalloproteinase inhibitor in focal ischemia in rat. J. Cereb. Blood Flow Metab. 2007, 27, 697-709. [CrossRef] [PubMed]

150. Jain, S.K.; Paul-Satyaseela, M.; Lamichhane, G.; Kim, K.S.; Bishai, W.R. Mycobacterium tuberculosis invasion and traversal across an in vitro human blood-brain barrier as a pathogenic mechanism for central nervous system tuberculosis. J. Infect. Dis. 2006, 193, 1287-1295. [CrossRef] [PubMed]

151. Namer, I.J.; Steibel, J.; Poulet, P.; Mauss, Y.; Mohr, M.; Chambron, J. The role of Mycobacterium tuberculosis in experimental allergic encephalomyelitis. Eur. Neurol. 1994, 34, 224-227. [CrossRef] [PubMed]

152. Antinori, A.; Arendt, G.; Becker, J.T.; Brew, B.J.; Byrd, D.A.; Cherner, M.; Clifford, D.B.; Cinque, P.; Epstein, L.G.; Goodkin, K.; et al. Updated research nosology for HIV-associated neurocognitive disorders. Neurology 2007, 69, 1789-1799. [CrossRef] [PubMed]

153. Martinez-Lopez, N.; Athonvarangkul, D.; Singh, R. Autophagy and aging. Adv. Exp. Med. Biol. 2015, 847, 73-87. [PubMed]

154. Shintani, T.; Klionsky, D.J. Autophagy in health and disease: A double-edged sword. Science 2004, 306, 990-995. [CrossRef] [PubMed]

155. Nah, J.; Yuan, J.; Jung, Y.K. Autophagy in neurodegenerative diseases: From mechanism to therapeutic approach. Mol. Cells 2015, 38, 381-389. [CrossRef] [PubMed]

156. Frake, R.A.; Ricketts, T.; Menzies, F.M.; Rubinsztein, D.C. Autophagy and neurodegeneration. J. Clin. Investig. 2015, 125, 65-74. [CrossRef] [PubMed]

157. Yamamoto, A.; Yue, Z. Autophagy and its normal and pathogenic states in the brain. Annu. Rev. Neurosci. 2014, 37, 55-78. [CrossRef] [PubMed]

158. Nedelsky, N.B.; Todd, P.K.; Taylor, J.P. Autophagy and the ubiquitin-proteasome system: Collaborators in neuroprotection. Biochim. Biophys. Acta 2008, 1782, 691-699. [CrossRef] [PubMed]

159. Radad, K.; Moldzio, R.; Al-Shraim, M.; Kranner, B.; Krewenka, C.; Rausch, W.D. Recent advances in autophagy-based neuroprotection. Expert Rev. Neurother. 2015, 15, 195-205. [CrossRef] [PubMed]

160. Zhu, X.C.; Yu, J.T.; Jiang, T.; Tan, L. Autophagy modulation for Alzheimer's disease therapy. Mol. Neurobiol. 2013, 48, 702-714. [CrossRef] [PubMed]

161. Smith, C.M.; Chen, Y.; Sullivan, M.L.; Kochanek, P.M.; Clark, R.S. Autophagy in acute brain injury: Feast, famine, or folly? Neurobiol. Dis. 2011, 43, 52-59. [CrossRef] [PubMed]

162. Quinby, G.E. Feasibility of prophylaxis by oral pralidoxime. Cholinesterase inactivation by organophosphorus pesticides. Arch. Environ. Health 1968, 16, 812-820. [CrossRef] [PubMed]

163. Omata, Y.; Lim, Y.M.; Akao, Y.; Tsuda, L. Age-induced reduction of autophagy-related gene expression is associated with onset of Alzheimer's disease. Am. J. Neurodegen. Dis. 2014, 3, 134-142.

164. Baldo, B.; Soylu, R.; Petersen, A. Maintenance of basal levels of autophagy in Huntington's disease mouse models displaying metabolic dysfunction. PLoS ONE 2013, 8, e83050. [CrossRef] [PubMed]

165. Xilouri, M.; Brekk, O.R.; Landeck, N.; Pitychoutis, P.M.; Papasilekas, T.; Papadopoulou-Daifoti, Z.; Kirik, D.; Stefanis, L. Boosting chaperone-mediated autophagy in vivo mitigates $\alpha$-synuclein-induced neurodegeneration. Brain 2013, 136, 2130-2146. [CrossRef] [PubMed]

166. Adhami, F.; Schloemer, A.; Kuan, C.Y. The roles of autophagy in cerebral ischemia. Autophagy 2007, 3, 42-44. [CrossRef] [PubMed] 
167. Zhu, C.; Wang, X.; Xu, F.; Bahr, B.A.; Shibata, M.; Uchiyama, Y.; Hagberg, H.; Blomgren, K. The influence of age on apoptotic and other mechanisms of cell death after cerebral hypoxia-ischemia. Cell Death Differ. 2005, 12, 162-176. [CrossRef] [PubMed]

168. Kabeya, Y.; Mizushima, N.; Ueno, T.; Yamamoto, A.; Kirisako, T.; Noda, T.; Kominami, E.; Ohsumi, Y.; Yoshimori, T. LC3, a mammalian homologue of yeast Apg8p, is localized in autophagosome membranes after processing. EMBO J. 2000, 19, 5720-5728. [CrossRef] [PubMed]

169. Rami, A.; Langhagen, A.; Steiger, S. Focal cerebral ischemia induces upregulation of Beclin 1 and autophagy-like cell death. Neurobiol. Dis. 2008, 29, 132-141. [CrossRef] [PubMed]

170. Vosler, P.S.; Graham, S.H.; Wechsler, L.R.; Chen, J. Mitochondrial targets for stroke: Focusing basic science research toward development of clinically translatable therapeutics. Stroke 2009, 40, 3149-3155. [CrossRef] [PubMed]

171. Petralia, R.S.; Schwartz, C.M.; Wang, Y.X.; Kawamoto, E.M.; Mattson, M.P.; Yao, P.J. Sonic hedgehog promotes autophagy in hippocampal neurons. Biol. Open 2013, 2, 499-504. [CrossRef] [PubMed]

172. Jimenez-Sanchez, M.; Menzies, F.M.; Chang, Y.Y.; Simecek, N.; Neufeld, T.P.; Rubinsztein, D.C. The Hedgehog signalling pathway regulates autophagy. Nat. Commun. 2012, 3, 1200. [CrossRef] [PubMed]

173. Liu, X.Y.; He, Y.J.; Yang, Q.H.; Huang, W.; Liu, Z.H.; Ye, G.R.; Tang, S.H.; Shu, J.C. Induction of autophagy and apoptosis by miR-148a through the sonic hedgehog signaling pathway in hepatic stellate cells. Am. J. Cancer Res. 2015, 5, 2569-2589. [PubMed]

174. Xiao, Q.; Yang, Y.; Qin, Y.; He, Y.H.; Chen, K.X.; Zhu, J.W.; Zhang, G.P.; Luo, J.D. AMP-activated protein kinase-dependent autophagy mediated the protective effect of sonic hedgehog pathway on oxygen glucose deprivation-induced injury of cardiomyocytes. Biochem. Biophys. Res. Commun. 2015, 457, 419-425. [CrossRef] [PubMed]

175. Gagne-Sansfacon, J.; Allaire, J.M.; Jones, C.; Boudreau, F.; Perreault, N. Loss of Sonic hedgehog leads to alterations in intestinal secretory cell maturation and autophagy. PLoS ONE 2014, 9, e98751. [CrossRef] [PubMed]

176. Li, H.; Li, J.; Li, Y.; Singh, P.; Cao, L.; Xu, L.J.; Li, D.; Wang, Y.; Xie, Z.; Gui, Y. Sonic hedgehog promotes autophagy of vascular smooth muscle cells. Am. J. Physiol. Heart Circ. Physiol. 2012, 303, H1319-H1331. [CrossRef] [PubMed]

177. Paulis, L.; Fauconnier, J.; Cazorla, O.; Thireau, J.; Soleti, R.; Vidal, B.; Ouille, A.; Bartholome, M.; Bideaux, P.; Roubille, F.; et al. Activation of Sonic hedgehog signaling in ventricular cardiomyocytes exerts cardioprotection against ischemia reperfusion injuries. Sci. Rep. 2015, 5, 7983. [CrossRef] [PubMed]

178. Ueda, K.; Takano, H.; Niitsuma, Y.; Hasegawa, H.; Uchiyama, R.; Oka, T.; Miyazaki, M.; Nakaya, H.; Komuro, I. Sonic hedgehog is a critical mediator of erythropoietin-induced cardiac protection in mice. J. Clin. Investig. 2010, 120, 2016-2029. [CrossRef] [PubMed]

179. Jia, G.; Cheng, G.; Agrawal, D.K. Autophagy of vascular smooth muscle cells in atherosclerotic lesions. Autophagy 2007, 3, 63-64. [CrossRef] [PubMed]

180. Jia, G.; Cheng, G.; Gangahar, D.M.; Agrawal, D.K. Insulin-like growth factor-1 and TNF- $\alpha$ regulate autophagy through c-jun N-terminal kinase and Akt pathways in human atherosclerotic vascular smooth cells. Immunol. Cell Biol. 2006, 84, 448-454. [CrossRef] [PubMed]

(C) 2018 by the authors. Licensee MDPI, Basel, Switzerland. This article is an open access article distributed under the terms and conditions of the Creative Commons Attribution (CC BY) license (http://creativecommons.org/licenses/by/4.0/). 